Portland State University

PDXScholar

$1-13-2022$

\title{
More Than Words: Articulating the Multisensory Experiences of Protected Area Visitors in Southern Nevada
}

Sara Nicole Temme

Portland State University

Follow this and additional works at: https://pdxscholar.library.pdx.edu/open_access_etds

Part of the Environmental Sciences Commons, and the Social and Cultural Anthropology Commons Let us know how access to this document benefits you.

\section{Recommended Citation}

Temme, Sara Nicole, "More Than Words: Articulating the Multisensory Experiences of Protected Area Visitors in Southern Nevada" (2022). Dissertations and Theses. Paper 5891.

https://doi.org/10.15760/etd.7762

This Thesis is brought to you for free and open access. It has been accepted for inclusion in Dissertations and Theses by an authorized administrator of PDXScholar. Please contact us if we can make this document more accessible: pdxscholar@pdx.edu. 


\begin{abstract}
More Than Words:
Articulating the Multisensory Experiences of Protected Area Visitors

in Southern Nevada
\end{abstract}

\author{
by \\ Sara Nicole Temme
}

A thesis submitted in partial fulfillment of the requirements for the degree of

Master of Arts

in

Anthropology

Thesis Committee:

Jeremy Spoon, Chair

Douglas Wilson

Douglas Deur

Portland State University

2021 
(C) 2021 Sara Nicole Temme 


\section{Abstract}

The complex sensory experiences of visitors to U.S. protected areas are not well understood. Previous research investigates visitor activities, motivations, and the ways place attachment cultivates support for conservation activities and other pro-environmental behavior. However, it is unclear how protected area visitor sensory experiences contribute to these behaviors. This study aims to articulate the multisensory experiences of visitors to the Desert National Wildlife Refuge Complex and the Spring Mountains National Recreation Area in southern Nevada, U.S.A. Specifically, it demonstrates the complexity of these experiences as present, intertwined, and embodied in all visit phases: before, during, and after. Utilizing a mixed-method investigation of a digitally administered survey $(n=141)$ and social media analysis of three major platforms where visitors post trip images and reviews, results from this study demonstrate the sensory experience of visitors to these protected areas is formulated in the memory and imagination of the visitor before their visit, embodied in their active physical engagement with the environment while on-site through their chosen activities, and cemented in their emotional recollection through internal and external processes. Further, visitors utilize photographs, reviews, and social media posts to create emotional artifacts of their visit, contributing to the anticipation of future visits and influencing proenvironmental behavior. These results can assist land managers in addressing planning and management decisions related to visitation, conservation, recreation, and interpretation. 


\section{Table of Contents}

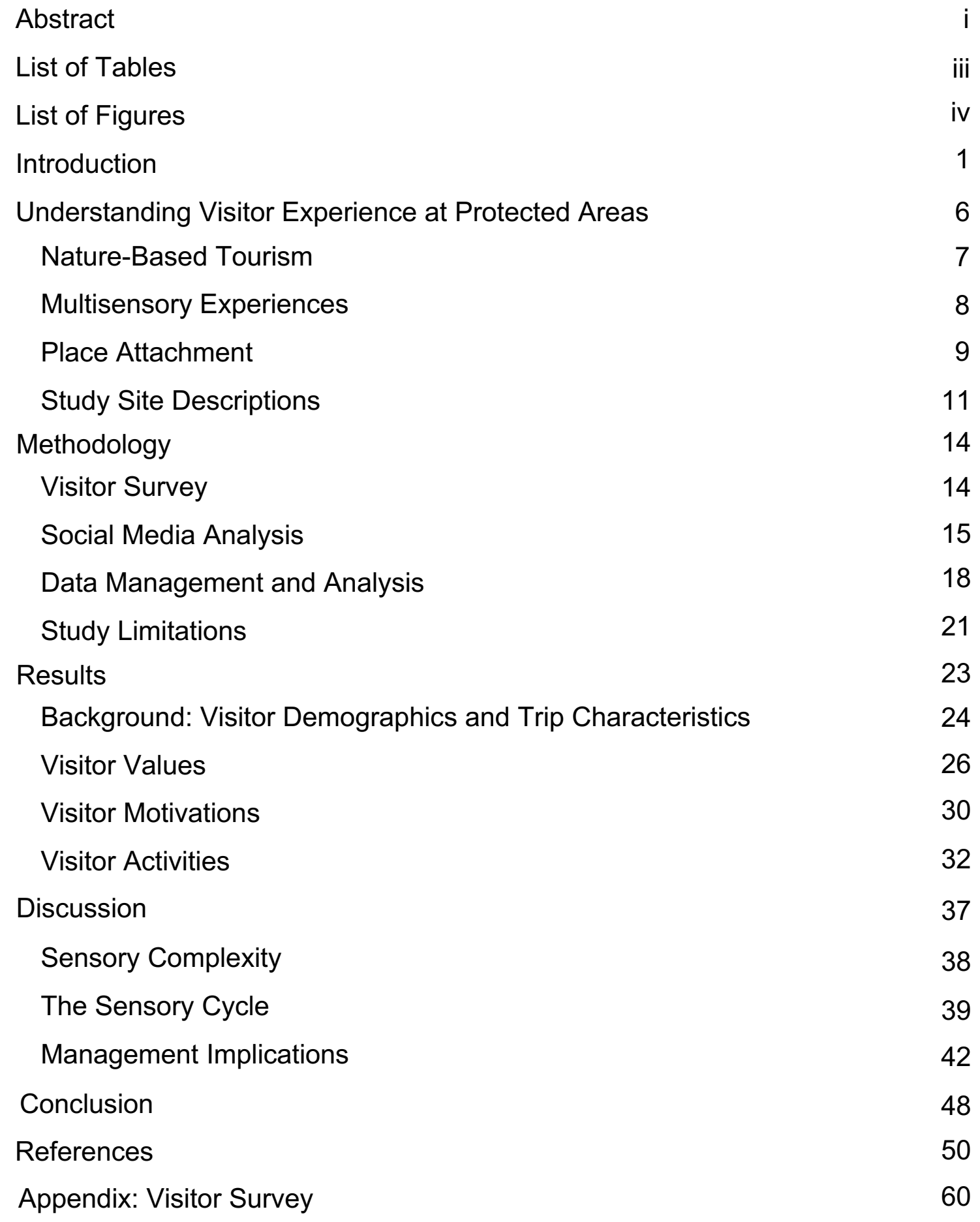




\section{List of Tables}

Table 1: Hashtags Used for Data Collection at Each Site 16

Table 2: Social Media Data Sample Sizes 17

Table 3: Sensory Categories Used in this Study 21

Table 4: Visitor Values Reported in Survey 27

Table 5: Visitor Emotions Expressed in Site Reviews 29

Table 6: Visitor Motivations Reported in Survey Responses 30

Table 7: Visitor Motivations Expressed in Hashtags 31

Table 8: Visitor Activities Described in Survey Responses 33

Table 9: Visitor Activities Described in Hashtags 35 


\section{List of Figures}

Figure 1: The Visitor's Sensory Cycle 


\section{Introduction}

In the United States, public lands managed by government entities ensure access to natural areas as an explicit right of the public (Comay et al. 2018). "Protected areas" are specific locations designated through policy for the conservation of natural and cultural resources, recreation for the enjoyment of natural spaces, and protection of historic and wild areas for public enjoyment (Department of the Interior 2016). Such spaces include National Wildlife Refuges managed by the U.S. Fish and Wildlife Service, and National Recreation Areas operated by the U.S. Forest Service and other federal agencies. Many social science researchers investigate the behaviors of visitors to protected areas through monitoring their activities and use patterns. However, they often overlook the complex emotional and sensory dimensions embedded into the visitor's experience.

The visitor's sensory experience in protected areas is multi-dimensional and meaningful (Brooks and Massengale 2011; Degnen 2016). Factors such as activities, motivations, perceptions, and post-visit impressions merge with memories, emotions, and in situ sensory activation to profoundly influence the visitor's sense of place- or, the meaning imbued by the visitor for a location (Tuan 1979)- and sense of belonging (Degnen 2016). An individual's previous experience with a specific site, other sites, and interactions with other visitors can also influence their perceptions of their experience (Lin and Lee 2020). Therefore, these sensory experiences are personal, significant, and often intangible. This paper aims to articulate the sensory experiences of visitors to four protected areas in 
southern Nevada using a digitally administered survey and social media analysis of three platforms. Further, it argues that these inherently multisensory experiences contribute to feelings of place attachment and may influence proenvironmental behaviors.

Researchers in various disciplines seek to understand visitors to protected areas, their behaviors, and their motivations. In the United States, studies of visitors to protected areas investigate carrying capacity (Fisichelli et al. 2015; Hamstead et al. 2018; Wood et al. 2013), visitor impact on natural and cultural resources (Monz et al. 2010), recreational behavior (Driver and Burns 2008; Manning 2011; Metcalf et al. 2013), and emotional attachment to place (Kil et al. 2012; Manning 2011) to cite a few significant avenues of study. These multi- and interdisciplinary inquiries research visitor behavior to help shape their experiences and create sustainable opportunities for visitors while maintaining these areas for public use. Notably, protected area managers have an investment in visitor behavior to identify planning objectives so that their multiple goals of public use, conservation, and stewardship can be addressed and maintained in both the short and long term (Brooks and Massengale 2011; Roggenbuck 2000). Therefore, a deep understanding of visitors' behaviors before, during, and after their time onsite is imperative for land managers for meeting a variety of objectives.

Understanding a more holistic visitor experience and emotional journey through a protected area can help managers identify site-specific visitor needs and preferences to aid in various planning processes (Roggenbuck 2000). For example, visitors with a history of repeat visitation will seek to experience previous 
emotions and sensory activation while on-site through the intensification of their activities (Fix et al. 2013). This intensification may occur through more consistent engagement with programming, on-site or event volunteering, sharing a beloved space with family and friends, acting as a knowledgeable guide, or exploring new areas outside of the well-trodden trails near the visitor center. Similarly, new visitors to a wildlife refuge may seek to view novel landscapes and recreate similar positive experiences by participating in activities such as hiking and taking photographs. Land managers could consider creating opportunities for these visitor experiences that account for engaging the senses in both active and passive ways.

This study aims to articulate the complex sensory experience of visitors to the Desert National Wildlife Refuge Complex (Desert NWRC) and the Spring Mountains National Recreation Area (SMNRA). Situated just outside of Las Vegas, Nevada, these sites comprise a variety of recreational opportunities for residents and visitors to Las Vegas. Visitors can choose self-guided exploration or guided tours, front country or back country excursions, day trips or extended stays- where amenities range from rustic dry camping to lodge accommodations. Some come with family to play in the snow; others embark on adventures to summit mountain peaks or stroll a boardwalk enjoying wildflower blooms. Lifelong associations with these sites motivate many to visit repeatedly, while others visit once and may never return. Whatever the motivations and activities a visitor participates in, all visitors to these protected area sites have complex, multisensory experiences during their visit. 
Utilizing a digitally administered visitor survey with 141 participants and a social media analysis of three major digital platforms, this study focuses on the visitor's emotional and sensory experiences in these specific study sites. Results indicate that the primary visitor is local to Las Vegas and the Southern Nevada region, participating in activities such as hiking, wildlife viewing, and photography. The themes of enjoying nature, feeling a sense of exploration, and sharing the outdoors with family and friends motivate visitors to visit these four sites, often repeatedly over a lifetime. The social media photos, associated captions and hashtags, and visitor reviews of sites further describe their activities, motivations, and emotions during their visit. For example, visitors often provide insights into their internal state in social media post descriptions: perceptions about the benefits and challenges of protected area recreation, support for conservation initiatives, and reflections about what they learned from site interpretation activities during their visit (Mehraliev et al. 2020). Embedded in these texts is the variety of senses activated through cognitive and physical means, often simultaneously. Visitors describe awe-inspiring views, cognitive activation through educational experiences, sore bodies from summiting peaks, and reflections on how their visit inspires their behaviors off-site. Through these analyses, site managers can consider engaging with visitors in ways that are most relevant to these users, based on their patterns of behavior associated with the specific site or during specific activities (Miller et al. 2019; Tenkanen et al. 2017; Wood et al. 2013). These behaviors can also indicate site-specific use patterns which may benefit planning objectives for conservation and recreation activities. 
The paper begins by framing the study with a brief discussion of theoretical frameworks related to nature-based tourism and place attachment to understand the methods, results, and findings. A discussion of the selected methods and data analysis then orient the reader to the type of data collected and analyzed for this study. I present results as a cyclical sensory journey using topics derived from the visitor survey: visitor demographics, trip characteristics, visitor values, motivations, and activities. Each topic incorporates results from both the visitor survey and the social media analysis to gain deeper insight into the sensory experience of the visitor. Through this mixed-method approach, I demonstrate how protected area visitation engages a broad spectrum of emotional and sensory experiences within the visitor- often simultaneously- contributing to feelings of complex place attachment for visitors to protected areas. This sense of place attachment may be unarticulated for the visitor, yet may influence pro-environmental behavior as a tangible outlet for the visitor's feeling of connection to certain "sensescapes" (Brehm et al. 2012). 


\section{Understanding Visitor Experience at Protected Areas}

Visitation to protected areas is an area of study across multiple disciplines, including leisure and tourism (Kil et al. 2012; Manning 2011), natural resource management (Brooks and Massengale 2011), ecological sciences (Miller et al. 2021; Sessions et al. 2016), and social sciences, such as anthropology (e.g., Graburn 1983; Graburn 1989; Urry 1992). Studies of visitor experience investigate a range of topics, including visitor tracking and estimating (Fisichelli et al. 2015; Hamstead et al. 2018; Wood et al. 2013), ecological impacts of recreational use (Monz et al. 2010), visitation preferences (Moyle et al. 2017), and evaluating the constraints to participation in outdoor recreation (Driver and Burns 2008; Manning 2011; Metcalf et al. 2013), to cite some examples. The variety of studies analyzing visitor experience in outdoor recreation and in protected areas reveals the complex nature of visitation and the myriad applications of its research.

Protected area managers seek to understand visitors' experience to balance visitor, land, and resource management objectives while accommodating complex agency directives and the needs of the public (Brooks and Massengale 2011). Understanding the visitor experience calls for the articulation of who the visitors are, what they do, and how they feel about their time at protected areas. These activities and sentimental experiences can consequently determine public support and participation in conservation activities- such as wildlife conservation, wetlands restoration, cultural resource and landscape protection, and public education- in the form of visitor engagement through activities both on-site and in their daily lives (Brooks and Massengale 2011; Manning 2011). The visitor's 
experience and their subsequent intrinsic creation of a personalized sense of place can incentivize visitors to aid in agency goals, especially on protected areas such as wildlife refuges and national forests. Therefore, leveraging these emotional experiences in traditional and experimental ways can lead to increased engagement and influence responsible visitor behavior.

\section{$\underline{\text { Nature-Based Tourism }}$}

Visitor experience at protected areas comprises a myriad of physical, geographic, emotional, and social factors, and its applications are multidimensional and diverse. To account for these diverse applications, this report employs the theoretical perspective of nature-based tourism to holistically frame the visitor's experience. Nature-based tourism theories relate personal and spiritual growth for individuals who seek communion with nature as a sort of "escape" from the stressors of daily life- where "nature" becomes a cathedral-like space (Cronon 1996, 3; Urry 1992, 9). Nature-seekers often build their experience around emotional goals, such as the desire to explore, and physical challenges such as isolation, mountain summiting, and withstanding rustic accommodations. These challenges serve as a method of creating an intense liminal or in-between space through "rites of intensification" and "rites of passage" (Conti and Cassel 2019; Graburn 1983). These rites or rituals serve to carry the participant from one status to the next, where the liminal space is one of ambiguity- the participant in this space is not who they once were, yet not yet who they will be upon their return (Turner 1967). Considering this liminality, visitors return from their journey feeling 
cleansed, refreshed, and more deeply connected to a sense of self and a sense of place. Some outdoor recreation theorists call the emotional connections visitors develop "place attachment" (Kil et al. 2012; Manning 2011), which describes their affect, attitudes, and behavioral patterns towards specific geographic locations.

\section{Multisensory Experiences}

Anthropologists utilize the study of the senses as both "objects of study and means of inquiry" (Howes 2019, 18) in a phenomenological, multidisciplinary approach (Pink 2010). A key concept from multisensory anthropology is "intersensoriality," where the multiple sensory experiences cannot be clearly separated from one another, but rather are constantly interacting (Howes 2019; Pink 2010). Thus, nature-based tourism inherently provides multisensory experiences for the visitor, as extracting individual sensations and separating them from one another is not possible (Dunne 2018; Pink 2010). For example, the act of identifying plants, a common activity of many visitors to protected areas, may be primarily visual, but plant identification can often involve tactile senses (touching leaves, seeds, or flowers) as well as olfactory (smelling leaves to inform identification) and even taste-based (for those seeking edible plants). Similarly, sensory experiences can be intensified or even disrupted by cognitive and social processes concurrently taking place (Desjarlais and Throop 2011). Memories triggered by the smell of certain plants may be highly individualistic based on the context and imagination of the individual engaging the olfactory experience (Bruce et al. 2015). Interactions with other visitors carry their own sensory experience, as 
well. For example, a crowded trail may disrupt visitors' physical, visual, auditory, and olfactory experience hoping to spend a quiet morning identifying birds at a wildlife refuge. The complexity of these sensory experiences, which some scholars refer to as "embodied" or "multi-sensuous" (Desjarlais and Throop 2011; Larsen and Urry 2011; Rakic and Chambers 2011; Urry 2002, 146), highlights the confluence of sensory activation taking place within the tourist in natural spaces. Therefore, some scholars utilize the term "sensescapes" to describe the visitor experience to natural areas like protected areas, indicating a holistic sensory experience in addition to landscape views and interactions (Bruce et al. 2015; Buzova et al. 2021; Dunne 2018).

\section{Place Attachment}

These multi-sensory experiences can also contribute to a visitor's emotional attachment to a place, including when visit frequency increases (Jorgensen and Stedman 2001; Vaske and Kobrin, 2001). Place attachment refers to the emotional connection visitors feel to a specific place, where cognition and action merge with emotional affect through thoughts and behaviors (Kyle and Chick 2007). This attachment originates in a person's "sense of place," where a landscape or space is imbued with value both individually and culturally (Kyle and Chick 2007, 212; Tuan 1979, 410). Thus, place attachment can occur as the result of childhood experiences, repeat visitation over several years, or a defining event in a person's life that occurred in a specific location (Kil et al. 2012; Kyle and Chick 2007; Manning 2011). For example, someone may develop an intense attachment 
to the landscape and setting of their family's favorite camping location or the place where they exchanged wedding vows. Place attachment develops and strengthens over time, and strongly correlates with the social experiences one has in that place (Jorgensen and Stedman 2001). Considering the critical nature of social interactions to inform place attachment, contemporary visitors to naturebased tourist locations utilize social media platforms as key storytelling locations to describe their emotional experiences, soliciting these "spiritual" journeys to both private and public audiences with posts, texts, hashtags, reviews, blogs, and vlogs (Conti and Cassel 2020; Conti and Lexhagen 2020; Miller et al. 2019). Thus, nature-based tourism is a social activity before, during, and after the initial "quest," where like-minded individuals create community and unique cultural norms.

Place-based experiences that influence place attachment can affect visitor behavior after the visit in the form of advocacy, financial support, social media activities, the desire to conserve wildlife and wilderness, and repeat visits. These activities become a part of the visitor's identity and sense of self (Lin and Lee 2019; Ramkissoon et al. 2012), embedded in the visitor's experience. Through their physical interactions with the environment, the constructed meaning of the journey or landscape, and the memory (both individual and social) that these relational and emotional experiences elicit within the visitor, person bonds to place (Degnen 2016; Jorgensen and Stedman 2001; Tuan 1979; Vaske and Kobrin 2001). Thus, place attachment becomes an important process for protected area visitors to develop emotional bonds, pro-environmental attitudes and values, and sustainable recreational behavior (Brehm 2012). 


\section{Study Site Descriptions}

The researcher selected these study sites as part of an ongoing partnership among the Desert National Wildlife Refuge Complex, Spring Mountains National Recreation Area, and the Office of Applied Anthropological Research at Portland State University (PSU). The U.S. Fish and Wildlife Service manages the Desert National Wildlife Refuge (Desert NWR), Ash Meadows National Wildlife Refuge (Ash Meadows NWR), Pahranagat National Wildlife Refuge (Pahranagat NWR), known collectively as the Desert National Wildlife Refuge Complex (Desert NWRC) or Desert Refuge Complex. The U.S. Forest Service manages the Spring Mountains National Recreation Area (Spring Mountains NRA), part of the Humboldt-Toiyabe National Forest, which spans much of the state of Nevada and parts of California. Since 2008, PSU has assisted both agencies in developing progressive consultation, resource management and interpretation frameworks and projects, especially in collaboration with Nuwu/Nuwuvi (Southern Paiute/Chemehuevi) tribes with ancestral ties to these protected areas (Spoon and Arnold 2012). Using ethnographic research, collaborative restoration, youth programs, and ongoing formal and informal tribal consultation (Spoon 2013, 2247), this long-term effort assists in addressing complex management and stewardship issues in both areas.

\section{Desert National Wildlife Refuge Complex}

Created in 1936 to provide habitat and protection for the desert bighorn sheep, the Desert NWR is home to a diverse landscape of 1.6 million acres- the 
largest refuge in the contiguous United States. The Desert Refuge Complex spans Southern Nevada from the Mojave to the Great Basin Desert. It comprises four refuges in Southern Nevada (Desert NWR, Ash Meadows NWR, Pahranagat NWR, and Moapa Valley NWR), managed together as the Desert National Wildlife Refuge Complex (DNWRC). The refuge complex features over 400 species of wildlife and over 500 plant species, many of which are endemic to the region (U.S. Department of the Interior, United States Fish and Wildlife Service 2021). Due to its size, the complex encompasses countless natural and culturally significant sites to Nuwu/Nuwuvi (Southern Paiute/Chemehuevi) and other associated Native American groups in the region (Spoon and Arnold 2012).

Spring Mountains National Recreation Area

The Spring Mountains National Recreation Area (Spring Mountains NRA or SMNRA), commonly referred to as Mount Charleston, is part of the more extensive Humboldt-Toiyabe National Forest, managed by the U.S. Forest Service (U.S. Department of Agriculture, Forest Service n.d.). Like the U.S. Fish and Wildlife Service, the USFS also works with conservation groups in tree planting, trail improvement, public education, and improving conditions at wildland/urban interfaces while promoting sustainable forest management and international efforts towards biodiversity conservation (U.S. Department of Agriculture, Forest Service n.d.). The Spring Mountains NRA is home to seven unique ecological zones, and more than two dozen endemic plant and animal species found only in the Spring Mountains (Sukach n.d.). It is also a critical location to Nuwu/Nuwuvi 
(Southern Paiute/Chemehuevi), who consider it a creation site when the world was new (Spoon and Arnold, 2012).

Located an hour from downtown Las Vegas, Nevada, both the Desert NWRC and the Spring Mountains NRA feature many recreational options for visitors, including hiking, camping, picnicking, skiing, and other seasonal activities for both day trips and extended stays. Visitors enjoy outdoor recreation activities year-round and these sites serve as a peaceful retreat from the urban activities of Las Vegas for both tourists and locals alike (SMNRA manager Deb Macneill, Personal Communication June 24, 2019). 


\section{Methodology}

The researcher participated in an internship with both federal agencies supervised by PSU to conduct? this research. This study utilized a mixed-method approach to understanding the visitor experience at the Desert National Wildlife Refuge Complex (DNWRC) and the Spring Mountains National Recreation Area (SMNRA) using an online visitor survey and a qualitative analysis of social media. Conducted during the COVID-19 pandemic of 2020, methods needed to accommodate remote field operations and no physical interaction with site visitors. Due to visitation and research restrictions from all four study locations and PSU, the researcher developed the study methods to accommodate remote activities and incorporate a social media analysis, which serves to identify how visitors represented their visit in their own words.

\section{Visitor Survey}

The survey instrument uploaded to Qualtrics online survey software for the duration of the study allowed for anonymous survey responses on July 1, 2020, until November 30, 2020. Of the 161 respondents who landed on the consent page, 141 continued to complete the entire survey $(\mathrm{N}=141)$. Study marketing materials in physical and digital formats, such as social media post images for distribution with partner organizations and printed posters to occupy A-frame signs at each of the four sites, included a unique web address generated for the study. The physical posters also included a scannable QR code, which visitors could scan with their smartphones and connect directly and anonymously to the online survey. 
The landing page for the online survey included the consent form with all pertinent study information, researcher contact information, and respondent age verification of 18 years. Respondents either consented to participate in the research study or declined to participate and redirected out of the survey.

Survey questions asked visitors what activities they participated in during their visit, the frequency of their visitation to the site, motivations for visiting, and demographics as a baseline for understanding the nature of the visit and the visitor. Other lines of inquiry in the survey addressed visitor values, activities, and responses to site interpretive elements. See Appendix for the survey instrument.

\section{$\underline{\text { Social Media Analysis }}$}

The researcher collected over 4,000 social media data units in the form of visitor reviews, photographs, photograph descriptions, captions, and hashtags publicly posted on Google Maps, Facebook, and Instagram to analyze content, themes, and correlations. These three platforms offered the highest amount of qualitative data for the study sites after preliminary social media analysis. Data collection from these sites began on July 30, 2020, a date selected using a random number generator to choose a number between 1 and 30 for beginning data collection in July 2020. Data collection required approximately eight days, completing collection from all three sources on August 7, 2020. Downloaded data stored in a secure external hard drive also featured password protection. Table 1 lists the hashtags used for the data collection on social media platforms for each site. 


\begin{tabular}{|l|r|}
\hline \multicolumn{2}{|c|}{ Table 1: Hashtags Used for Data Collection at Each Site } \\
\hline \multicolumn{1}{|c|}{ Site } & \multicolumn{1}{|c|}{ Hashtag } \\
\hline Ash Meadows NWR & \#ashmeadowsnwr \\
\hline & \#ashmeadowsnationalwildliferefuge \\
\hline Desert NWR & \#desertnwr \\
\hline Pahranagat NWR & \#dertnationalwildliferefuge \\
\hline & \#pahranagatnwr \\
\hline Spring Mountains NRA & \#pahranagatnationalwildliferefuge \\
\hline & \#mountcharleston \\
\hline & \#mtcharleston \\
\hline
\end{tabular}

A sample drawn from each data set ensured the manageability of the data while remaining statistically sound for analysis. The sample size determination utilized a sample size calculator on Qualtrics.com. Qualtrics uses Cochran's formula for determining sample size in study populations:

Necessary Sample Size $=(Z-s c o r e)^{2}-S_{\text {StdDev }}(1-S t d D e v) /(\text { margin of error })^{2}$ Where the margin of error is $5 \%$, and the standard deviation (StdDev) is 0.5 . A Zscore is a standardized measure of "expressing the distance of a variate from the mean" or the distance from the mean in standard deviations (Williams and Quave $2019,66)$. Using a Z-score calculator table where the confidence level is $95 \%$, a Z-score is 1.96 (Smith 2020), deriving the sample size from the total number in the population within 1.96 standard deviations from the mean. 


\begin{tabular}{|c|c|c|}
\hline Source & Total Units & Sample Size \\
\hline \multicolumn{3}{|l|}{ Desert NWR } \\
\hline Google Reviews and Photos & 413 & 251 \\
\hline Facebook Reviews and Photos & 115 & 101 \\
\hline Instagram Posts & 412 & 199 \\
\hline Total Units & 940 & 551 \\
\hline \multicolumn{3}{|l|}{ Ash Meadows NWR } \\
\hline Google Reviews and Photos & 191 & 149 \\
\hline Facebook Reviews and Photos & 118 & 103 \\
\hline Instagram Posts & 508 & 219 \\
\hline Total Units & 817 & 471 \\
\hline \multicolumn{3}{|l|}{ Pahranagat NWR } \\
\hline Google Reviews and Photos & 508 & 306 \\
\hline Facebook Reviews and Photos & 9 & 9 \\
\hline Instagram Posts & 238 & 147 \\
\hline Total Units & 755 & 462 \\
\hline \multicolumn{3}{|l|}{ Spring Mountains NRA } \\
\hline Google Reviews and Photos & 434 & 354 \\
\hline Facebook Reviews and Photos & 439 & 273 \\
\hline Instagram Posts & 569 & 230 \\
\hline Total Units & 1442 & 857 \\
\hline Total Aggregated Units & 4,954 & 2,341 \\
\hline
\end{tabular}

Table 2 shows the original data units collected at each site and sample analyzed using the above formula. Units in each data set were numbered in order starting with 1 . The researcher then utilized a random number generator to determine which units to pull for analysis in each data set, extracted and isolated units corresponding with the random numbers, and archived the non-corresponding files. This sampling method ensured a manageable data set that produced a representative sample to provide reliable insight into visitors' experience to each site at this time (Roberge 2014, 717-719). 


\section{Data Management and Analysis}

The researcher stored all quantitative and qualitative data in passwordprotected digital files and backed up to an external, password-protected hard drive and cloud storage device every three days. Data entry and organization for the social media analysis took place during the months when the survey was active online, from July to November of 2020. Data entry and organization for the survey instrument took place after the collection period, in December 2020.

Statistical analysis treated the survey and social media data as unique data sets for statistical analysis, then aggregated them for a universal analysis. Descriptive statistics of variables in each data set provided a preliminary look at the results. Then, a cross-tabulation analysis of survey results determined select patterns related to visitor demographics, site activities, visitor motivations, and potential recommendations. These analyses utilized Microsoft (MS) Excel, Google Sheets, and Statistical Package for Social Sciences (IBM SPSS V27).

The researcher downloaded the visitor survey from the Qualtrics platform into Excel spreadsheets for analysis, then organized them into fields appropriate for descriptive statistics and cross-tabulation analyses. Analysis began with a simple tabulation of total responses for each response option to create data tables and graphs for the report (Bernard 2006, 451). Then, site-specific surveys separated into individual spreadsheets contributed to a side-by-side comparison of all four study sites. This analysis treated qualitative responses from the survey according to the same coding themes as the social media analysis and interviews, 
discussed in the following paragraphs. The researcher then uploaded the spreadsheets into SPSS to analyze the variables.

The researcher analyzed qualitative responses, social media images, and text with a manifest content analysis technique, where the researcher systematically applies a set of codes or variables to a text (Bernard 2006, 507). General coding of qualitative data began using the predetermined themes and activities presented in the visitor survey: values, motivations, and activities. Infrequently, the researcher inductively added a new code to supplement activities and motivations described in a social media post (Bernard 2006, 493). For example, supplemental activities present in the social media data set but not offered as an option in the visitor survey were rock climbing and stargazing. Qualitative responses and site reviews also included codes for tone (positive/neutral/negative) and emotional or sentimental value, such as happy, disappointed, and satisfied (Saldaña 2016).

The analysis treated each hashtag as a unique attribute in the Atlas.ti coding software, an ad-hoc technique adopted by the researcher during coding to accurately analyze hashtags as a sub-data set (Saldaña 2016, 83). Posts could feature up to 30 "hashtags" used by social media platforms to allow users to "follow" themes, events, and ideas by using the symbol \# followed by a qualitative "tag," for example, \#nevada or \#hiking. These hashtags also described various visitor experience variables such as location, activity, sentiment or emotional state, and motivation. After completing all qualitative coding, a quantitative analysis of code frequency helped determine the most prevalent visitor activities, motivations, 
opinions, and other experience variables. Then, the researcher coded the entire data set of hashtags according to existing and emergent themes during the second round of coding. For example, emergent code groups helped identify specific themes related to attributes, such as hashtags about environmental science, through pattern coding (Saldaña 2016, 236). Pattern coding groups specific attributes into meaningful themes by summarizing data. This process served to place the data in conversation with the survey results, expand upon existing themes, and create depth in the qualitative analysis.

When possible, social media posts used similar demographic codes to the survey. For example, if the reviewer had a profile photo or profile name indicating their gender, geographic origin, or ethnic demographic category, it was includedi.e., "LasVegasLarry" with a picture of a white male was coded white, male, local. However, this demographic coding occurred infrequently, as many social media users create pseudonyms and profile pictures not depicting themselves- such as landscapes, characters from media, or images of family groups.

The researcher assigned each category (visitor values, visitor motivations, and visitor activities) a supplementary sensory field to identify trends in visitor sensory experiences (Table 3). The categories defined here include the five commonly accepted physical senses (sight, sound, touch, taste, and smell) and other sensory or emotional experiences described as cognitive, emotional, physical, and social. These additional sensory categories aim to capture the depth of sensation that protected area visitation and outdoor recreation can elicit in visitors. 


\begin{tabular}{|l|l|l|}
\hline \multicolumn{1}{|l|}{ Table 3: Sensory Categories Used in this Study } \\
\hline Category & \multicolumn{1}{|c|}{ Definition } & \multicolumn{1}{|c|}{ Examples } \\
\hline Auditory & sounds or silence, primarily something to hear or listen to & $\begin{array}{l}\text { "enjoy the sounds of } \\
\text { nature" }\end{array}$ \\
\hline Cognitive & engaging educational, mental, or thoughtful reflection & $\begin{array}{l}\text { "reflect on my place } \\
\text { in the world" }\end{array}$ \\
\hline Emotional & $\begin{array}{l}\text { engaging emotional response or feelings of satisfaction, } \\
\text { pride, anticipation, or fear }\end{array}$ & $\begin{array}{l}\text { "feel a sense of } \\
\text { exploration" }\end{array}$ \\
\hline Physical & $\begin{array}{l}\text { creates a physical sensation, releases endorphins, } \\
\text { involves whole body processes }\end{array}$ & "hiking" \\
\hline Smell & $\begin{array}{l}\text { experienced through smell or smell contributes to sensory } \\
\text { experience }\end{array}$ & "smell wildflowers" \\
\hline Social & $\begin{array}{l}\text { socially engaging experiences that require interaction with } \\
\text { others or are enhanced by social interaction }\end{array}$ & $\begin{array}{l}\text { "share outdoors with } \\
\text { family and friends" }\end{array}$ \\
\hline Tactile & engaging touch or experienced through touch & "rock climbing" \\
\hline Taste & experienced through taste, through eating or drinking & "foraging" \\
\hline Visual & $\begin{array}{l}\text { visually engaging or stimulating, primarily something to } \\
\text { look at }\end{array}$ & "viewing scenic \\
beauty"
\end{tabular}

\section{Study Limitations}

Limitations are present both within the methodology and results. First, during the initial survey implementation, a researcher error occurred in which a prompt for visitor age was omitted. Age was therefore not used as a variable in subsequent data analysis. Second, a visitor survey limits the visitor's expression of their whole emotional and sensory experience. Therefore, a more appropriate method for future researchers should design instruments with as many qualitative response options as possible- either in the form of a qualitative response survey, in-depth interviews, or participatory methods with the research participants. Similarly, the original survey design did not consider olfactory activation. While it did not emerge as a theme from the inductive analysis of social media reviews, 
images, or other associated text, authors note that without direct questioning of an olfactory experience or "smellscape," visitors may not comment on its importance except for in certain circumstances (Franco et al. 2017; Rice et al. 2019). Therefore, a more in-depth and qualitative investigation into these sensory experiences and the specific ways they can contribute to pro-environmental behavior on protected areas would be a fruitful line of inquiry.

Additionally, the survey distribution and social media analysis utilized voluntary respondents through impersonal on-site and social media marketing materials and publicly posted user-generated content, therefore the sample here represents only those visitors willing to participate in this research, or who posted to social media during a specific time frame and may not represent the opinions of all visitors. As scholars of social media research note, demographics of social media users are not representative of the general public (Laestadius 2018), as they tend to be younger, female, and of more diverse racial/ethnic backgrounds than the average protected area visitor (Pew Research Center 2021). Social media users are therefore an interesting locale for public land research, as they may contribute significant insight to the qualitative experiences of visitors ( $\mathrm{Di}$ Minnen et al. 2015), but may not represent the visitor experience of a more general visitor public to these four study sites. Researchers conducting on-site survey recruitment with visitors may identify more granular information about survey participants, including demographics, and may recruit a greater diversity of participants than a self-serve survey or public social media posts. 


\section{$\underline{\text { Results }}$}

Visitor experience at protected areas encompasses a complex mix of variables. The visitor develops goals and expectations for their visit, influenced by their socioeconomic status, experience with outdoor recreation, previous experience at protected areas, physical capabilities, and emotional motivations. Additionally, interaction with on-site features like amenities, environmental factors, and other visitors can influence the overall satisfaction with meeting those sensory goals- resulting in a net-positive or net-negative experience. Some factors that influence sensory experiences are outside the control of either the visitor or the land manager- for example, climate or weather conditions, or public health directives that dictate appropriate recreational locations. The mixed methods utilized in this study aimed to distill the visitor experience into measurable variables, categorizing the types of activities, visitor motivations, and the use of social media on public internet platforms to represent visitation while bringing the sensory experience to life throughout the visitor's journey.

The researcher presents select results here related to multisensory visitor experiences (for full results of the visitor survey and social media analysis, see Temme and Spoon 2021). The results shared in this paper begin with background trends in demographics that include race/ethnicity, income, education and employment status. Trip characteristics articulate the visitor's time spent on-site, where they traveled from, and information about their mode of transportation. Visitor values expand on higher-level motivations for visiting protected areas, such as the desire to be close to nature and align personal values with recreational 
activities. Activities and motivations break down the variety of activities that visitors participate in and the reasons they chose those specific activities. Critically, this analysis of these domains of visitor values, activities, and motivations help researchers to interrogate the various sensory experiences before, during, and after their time on-site.

The tables presented in each section summarize the quantitative responses collected from the visitor survey, followed by the corresponding results from the social media analysis. The tables show combined results for the Desert National Wildlife Refuge as a complex (Desert NWR, Ash Meadows NWR, and Pahranagat NWR), Spring Mountains National Recreation Area, and all sites combined (Desert NWR, Ash Meadows NWR, Pahranagat NWR, and Spring Mountains NRA). Each column states how many surveys are in the category, and each question displays the number of responses. Lastly, the tables show the number of responses ( $n$ ) alongside the percentage of answers for each question (\%).

\section{Background: Visitor Demographics and Trip Characteristics}

Understanding the visitor's experience begins with baseline information about who the visitor is and where they reside, presented here as visitor demographics and trip characteristics. These data points contribute to the context of the visitor and their sensory motivations, as well as their attachment to place and future visit intentions. The demographic survey shows most respondents identified their race or ethnicity as White or of European descent (84\%), while a minority of visitors identified as Black or African descent, Asian, Hispanic or 
Latino/a, and Native American (17\%, all four categories combined). Contrary to comparable visitation studies, $71 \%$ of respondents to this survey were female, where gender distributions in previous research were approximately $40 \%$ female, 60\% male (Dietsch et al. 2019; USDA Forest Service FY 2016). This anomaly may be due to the mode of survey administration, which may have been more attractive to female visitors, or the unique pandemic conditions influencing visitation activities in 2020. Survey respondents reported completion of some college (34\%), bachelor's degrees (21\%), and graduate school (27\%). The majority of respondents reported full-time employment $(58 \%)$ or retired $(13 \%)$ and earned approximately $\$ 75 \mathrm{~K}$ average annual income. While these demographics are congruent with past studies of these protected areas (Dietsch et al. 2019; USDA Forest Service FY 2016), they do differ from the demographics of the Las Vegas area, which the U.S. Census Bureau estimates as $43.5 \%$ white, with an average annual income of $\$ 56,000$, and where $24.6 \%$ of residents hold a bachelor's degree or higher (U.S. Census Bureau).

Trip characteristics detail the visitor's travel behavior and length of stay, contributing to the understanding of the sensory journey of the visitor on the day of their trip. Questions about trip characteristics included how the visitor heard about the site, how the visitor traveled, number of lifetime visits, what seasons they visited, and if they intend to return in the next twelve months. Most visitors to Desert NWRC and Spring Mountains NRA are local to Las Vegas and Southern Nevada. These local visitors are familiar with the area and $87 \%$ have visited these sites several times, some claiming lifelong affiliation and knowledge of specific 
locations. They have experience visiting in every season of the year somewhat evenly, with fall months (September through November) showing slightly higher visitation than other seasons. Visitors travel by personal vehicle and often travel with family and friends. Most report spending between 2 and 4 hours on-site during their visit and between 1 and 3 days for extended stays like camping trips. Many have long-term knowledge of the refuges and the recreation area and readily claim emotional attachment to these places.

\section{$\underline{\text { Visitor Values }}$}

Intrinsic values described by visitors are multisensory, where visitors desire to engage cognitive and emotional senses during their visit. The survey included a five-question, five-point Likert-scale response related to visitor values (Table 4). These five questions comprise cognitive and emotional sensory experiences, causing the visitor to reflect on their experiences during their time on site. Many respondents experience cognitive activation through introspective thought processes, including identifying their personal values and the value of the protected areas previously visited. These values also signal intangible aspects that require the visitor's agency in the form of making plans, engaging in activities, and preparing for their physical and emotional journey in situ. Visitor values also engage with broader pro-environmental behaviors, such as avoiding littering or advocating for conservation activities.

Visitors reflected on their beliefs, relationship to nature, and appreciation of protected areas, where the response options were completely agree, somewhat 
agree, neutral, somewhat disagree, and completely disagree (Table 4). Of the five questions posed, the two with the highest percentage of respondents completely agreed that they deepened my appreciation for public lands (79\%), and I improved my connection with nature (74\%). Approximately $1-3 \%$ of visitors responded completely disagree with all five questions related to values.

\begin{tabular}{|c|c|c|c|c|c|c|c|c|}
\hline \multicolumn{9}{|c|}{ Table 4: Visitor Values Reported in Survey } \\
\hline 0 & 10 & 20 & 40 & 50 & 70 & 80 & 90 & 100 \\
\hline \multicolumn{9}{|c|}{ Percent of Respondents } \\
\hline & & \multicolumn{2}{|c|}{$\begin{array}{l}\text { Desert NWR Complex } \\
\qquad N=96\end{array}$} & \multicolumn{2}{|c|}{$\begin{array}{l}\text { Spring Mountains NRA } \\
\qquad N=94\end{array}$} & \multicolumn{3}{|c|}{$\begin{array}{l}\text { All Sites Combined } \\
\qquad N=190\end{array}$} \\
\hline & & $N$ & $\%$ & $n$ & $\%$ & $n$ & \multicolumn{2}{|r|}{$\%$} \\
\hline \multicolumn{9}{|c|}{ During my visit to this site, I have thought about my personal values. } \\
\hline & & \multicolumn{2}{|c|}{$N=87$} & \multicolumn{2}{|c|}{$N=82$} & \multicolumn{3}{|c|}{$N=169$} \\
\hline \multicolumn{2}{|c|}{ Completely Agree } & 28 & $32 \%$ & 37 & $45 \%$ & 65 & \multicolumn{2}{|c|}{$38 \%$} \\
\hline \multicolumn{2}{|c|}{ Somewhat Agree } & 49 & $56 \%$ & 26 & $32 \%$ & 75 & \multicolumn{2}{|c|}{$44 \%$} \\
\hline \multicolumn{2}{|r|}{ Neutral } & 9 & $10 \%$ & 13 & $16 \%$ & 22 & \multicolumn{2}{|c|}{$13 \%$} \\
\hline \multicolumn{2}{|c|}{ Somewhat Disagree } & 0 & $0 \%$ & 2 & $2 \%$ & 2 & \multicolumn{2}{|r|}{$1 \%$} \\
\hline \multicolumn{2}{|c|}{ Completely Disagree } & 1 & $1 \%$ & 4 & $5 \%$ & 5 & & $3 \%$ \\
\hline \multicolumn{9}{|c|}{ During my visit to this site, I have thought about my place in the world. } \\
\hline & & \multicolumn{2}{|c|}{$N=84$} & \multicolumn{2}{|c|}{$N=81$} & \multicolumn{3}{|c|}{$N=165$} \\
\hline Con & etely Agree & 40 & $48 \%$ & 38 & $47 \%$ & 78 & & $48 \%$ \\
\hline Sor & what Agree & 29 & $35 \%$ & 28 & $35 \%$ & 57 & & $34 \%$ \\
\hline & Neutral & 12 & $14 \%$ & 9 & $11 \%$ & 21 & & $13 \%$ \\
\hline Some & lat Disagree & 2 & $2 \%$ & 2 & $2 \%$ & 4 & & $2 \%$ \\
\hline Compl & ely Disagree & 1 & $1 \%$ & 4 & $5 \%$ & 5 & & $3 \%$ \\
\hline
\end{tabular}


Table 4: Visitor Values Reported in Survey cont.

\begin{tabular}{|l|l|l|l|l|l|l|l|l|l|l|}
\hline \multicolumn{10}{|c|}{ Color Key } \\
\hline 0 & 10 & 20 & 30 & 40 & 50 & 60 & 70 & 80 & 90 & 100 \\
\hline \multicolumn{10}{|c|}{ Percent of Respondents } \\
\hline
\end{tabular}

During my visit to this site, I have improved my connection with nature.

\begin{tabular}{|r|c|c|c|c|c|c|}
\hline & \multicolumn{2}{|c|}{$N=87$} & \multicolumn{2}{c|}{$N=81$} & \multicolumn{3}{c|}{$N=168$} \\
\hline Completely Agree & 59 & $68 \%$ & 65 & $80 \%$ & 124 & $74 \%$ \\
\hline Somewhat Agree & 22 & $25 \%$ & 10 & $12 \%$ & 32 & $19 \%$ \\
\hline Neutral & 6 & $7 \%$ & 3 & $4 \%$ & 9 & $5 \%$ \\
\hline Somewhat Disagree & 0 & $0 \%$ & 0 & $0 \%$ & 0 & $0 \%$ \\
\hline Completely Disagree & 0 & $0 \%$ & 3 & $4 \%$ & 3 & $2 \%$ \\
\hline
\end{tabular}

During my visit to this site, I have improved my understanding of human and nature relationships.

\begin{tabular}{|r|c|c|c|c|c|c|}
\hline & \multicolumn{2}{|c|}{$N=87$} & \multicolumn{2}{c|}{$N=80$} & \multicolumn{2}{c|}{$N=167$} \\
\hline Completely Agree & 29 & $33 \%$ & 36 & $45 \%$ & 65 & $38 \%$ \\
\hline Somewhat Agree & 43 & $49 \%$ & 28 & $35 \%$ & 71 & $43 \%$ \\
\hline Neutral & 13 & $15 \%$ & 11 & $14 \%$ & 24 & $15 \%$ \\
\hline Somewhat Disagree & 1 & $1 \%$ & 1 & $1 \%$ & 1 & $1 \%$ \\
\hline Completely Disagree & 1 & $1 \%$ & 4 & $5 \%$ & 5 & $3 \%$ \\
\hline
\end{tabular}

During my visit to this site, I have deepened my appreciation for public lands.

\begin{tabular}{|r|c|c|c|c|c|c|}
\hline & \multicolumn{2}{|c|}{$N=87$} & \multicolumn{2}{c|}{$N=80$} & \multicolumn{2}{c|}{$N=167$} \\
\hline Completely Agree & 69 & $79 \%$ & 62 & $78 \%$ & 131 & $79 \%$ \\
\hline Somewhat Agree & 18 & $21 \%$ & 12 & $15 \%$ & 30 & $18 \%$ \\
\hline Neutral & 0 & $0 \%$ & 4 & $5 \%$ & 4 & $3 \%$ \\
\hline Somewhat Disagree & 0 & $0 \%$ & 0 & $0 \%$ & 0 & $0 \%$ \\
\hline Completely Disagree & 0 & $0 \%$ & 2 & $3 \%$ & 2 & $1 \%$ \\
\hline
\end{tabular}

Visitors frequently utilize social media posts and reviews to discuss their values related to public land use, recreation activities, and their sensory journeys while on-site. In site reviews, specifically, visitors often described their emotional 
state during their visit (Table 5). The most expressed emotion in visitor reviews was awe (41\%) and satisfaction (26\%) with their experience. Many visitors expressed happiness (14\%) and surprise (9\%), frequently at the site's beauty or solitude. When visitors noted emotion, approximately $5 \%$ expressed disappointment with their visit, usually associated with visitor experience not meeting visitor expectations.

Table 5: Visitor Emotions Expressed in Site Reviews

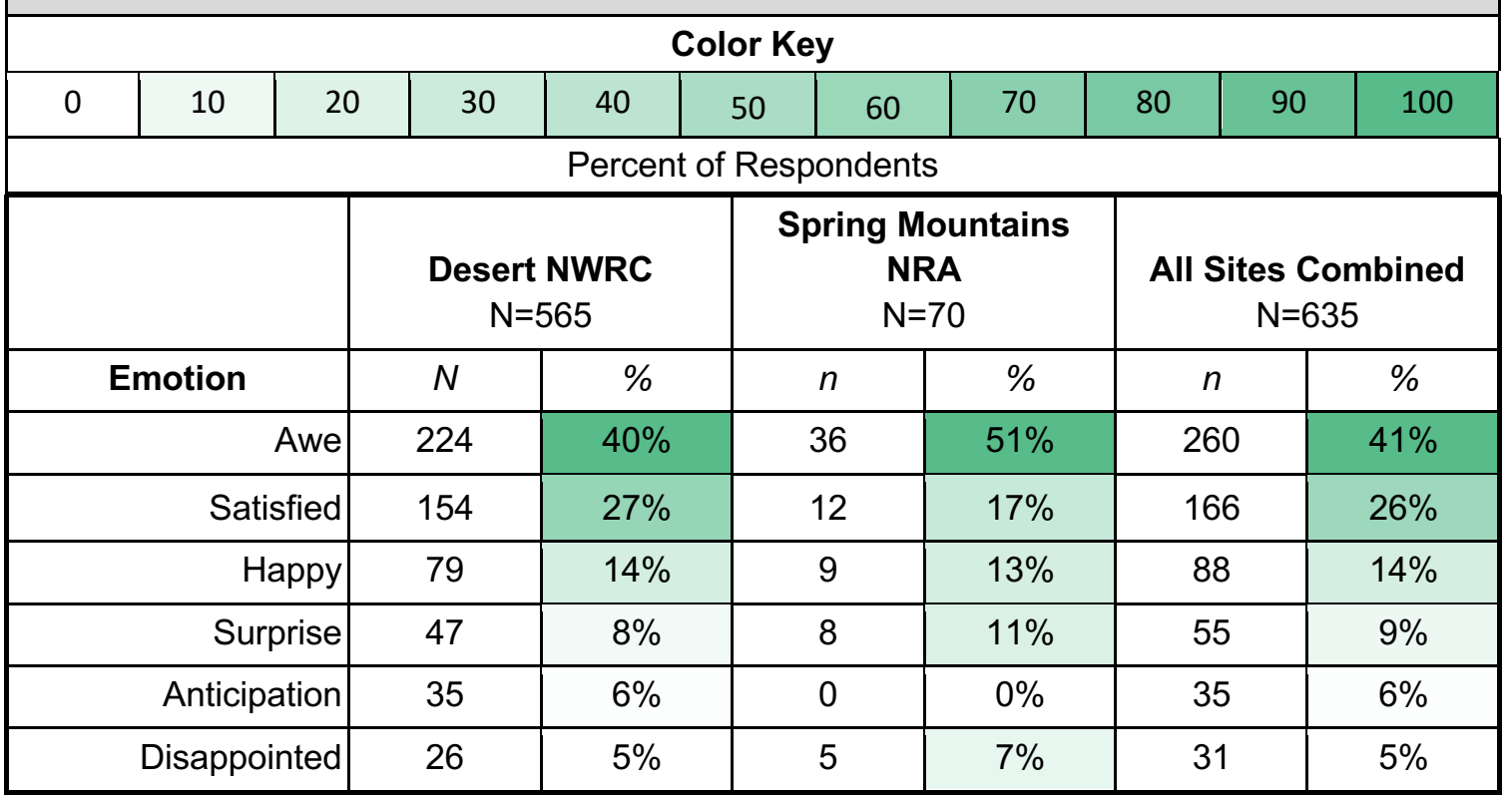

These emotional expressions in social media posts represent the visitor's intrinsic experience, expressed verbally or through text or the use of hashtags. Created on-site or after their visit, visitors express a spectrum of emotional experiences in these posts. Each unique visitor experiences a variety of emotional states before, during, and after their visit. Therefore, these emotional expressions in social media posts and reviews represent a visible artifact of the intangible elements of their experiences. 


\section{$\underline{\text { Visitor Motivations }}$}

Motivations described by visitors are multisensory, where visitors desire to engage visual, cognitive, auditory, social, and physical senses during their visit (Table 6). These motivations reflect the visitor's sensory expectations, as well as the desire to reproduce previous sensory experiences. Motivations will inform which activities they plan for their visit, depending on the type of sensory experience they seek.

\begin{tabular}{|c|c|c|c|c|c|c|c|c|c|}
\hline \multicolumn{10}{|c|}{ Color Key } \\
\hline 0 & 10 & 20 & 30 & 40 & 50 & 60 & 80 & 9 & 100 \\
\hline \multicolumn{10}{|c|}{ Percent of Respondents } \\
\hline & & & & \multicolumn{2}{|c|}{$\begin{array}{l}\text { Desert NWR } \\
\text { Complex } \\
\mathrm{N}=96\end{array}$} & \multicolumn{2}{|c|}{$\begin{array}{c}\text { Spring Mountains } \\
\text { NRA } \\
N=94\end{array}$} & \multicolumn{2}{|c|}{$\begin{array}{l}\text { All Sites Combined } \\
\qquad \mathrm{N}=190\end{array}$} \\
\hline $\begin{array}{l}\text { Sensory } \\
\text { Category }\end{array}$ & \multicolumn{3}{|c|}{ Motivation } & $n$ & $\%$ & $n$ & $\%$ & $n$ & $\%$ \\
\hline Visual & \multicolumn{3}{|c|}{ View Scenic Beauty } & 94 & $98 \%$ & 91 & $97 \%$ & 185 & $97 \%$ \\
\hline Cognitive & & \multicolumn{2}{|c|}{ Be Close to Nature } & 87 & $91 \%$ & 91 & $97 \%$ & 178 & $94 \%$ \\
\hline Cognitive & \multicolumn{3}{|c|}{ Experience Tranquility } & 72 & $75 \%$ & 83 & $88 \%$ & 155 & $82 \%$ \\
\hline Auditory & \multicolumn{3}{|c|}{$\begin{array}{r}\text { Enjoy the Sounds of } \\
\text { Nature }\end{array}$} & 61 & $64 \%$ & 77 & $82 \%$ & 138 & $73 \%$ \\
\hline Social & \multicolumn{3}{|c|}{$\begin{array}{r}\text { Share the Outdoors } \\
\text { with Family and Friends }\end{array}$} & 57 & $59 \%$ & 72 & $77 \%$ & 129 & $68 \%$ \\
\hline Cognitive & \multicolumn{3}{|c|}{$\begin{array}{r}\text { Experience sense of } \\
\text { Exploration }\end{array}$} & 57 & $59 \%$ & 61 & $65 \%$ & 118 & $62 \%$ \\
\hline Physical & \multicolumn{3}{|c|}{ Escape the Heat } & 25 & $26 \%$ & 78 & $83 \%$ & 103 & $54 \%$ \\
\hline Physical & \multicolumn{3}{|c|}{ Enjoy the Snow } & 10 & $10 \%$ & 63 & $67 \%$ & 73 & $38 \%$ \\
\hline Social & \multicolumn{3}{|c|}{ Share on Social Media } & 30 & $31 \%$ & 39 & $41 \%$ & 69 & $36 \%$ \\
\hline
\end{tabular}

Visitor motivations for planning site visits are diverse. Still, the primary motivations are to view scenic beauty (97\%), be close to nature (94\%), experience 
tranquility $(82 \%)$, enjoy the sounds of nature $(73 \%)$, share the outdoors with family and friends (68\%) and experience a sense of exploration (62\%) (Table 6). Visitors to the Spring Mountains National Recreation Area also have a high interest in escaping the heat of Las Vegas (83\%), enjoying the snow (67\%), and sharing photos on social media (41\%).

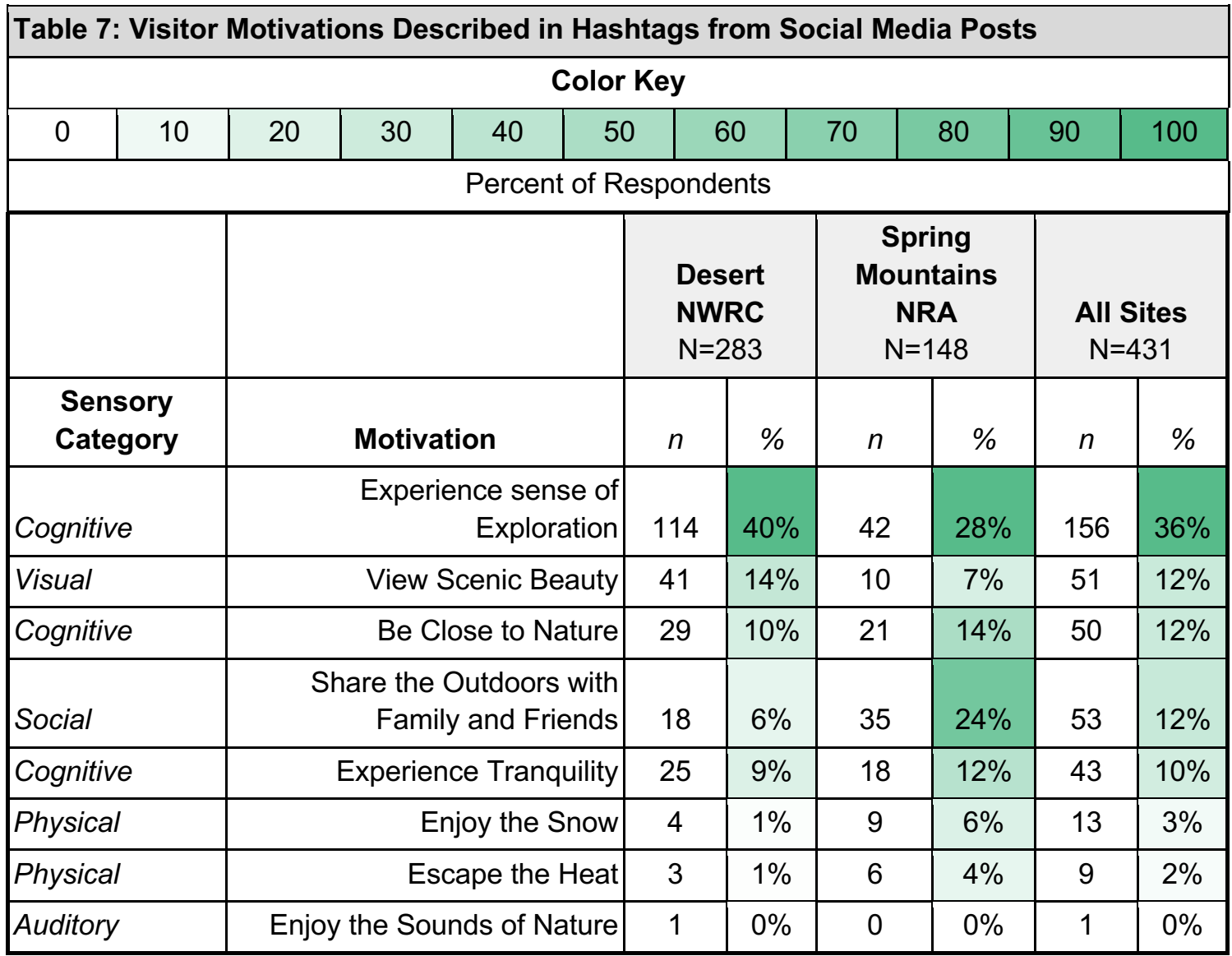

Table 7 compares hashtag attributes to the same motivations as the survey. Across the entire data set of all hashtags used, those hashtags describing visitor motivations occurred about $12 \%$ of the time across all four study sites. Of these, the most frequent theme was the desire to experience a sense of exploration (36\%), followed by the desire to share the outdoors with family and friends $(12 \%)$, 
view scenic beauty $(12 \%)$, and be close to nature (12\%). Spring Mountains NRA indicated higher percentages of visitors sharing their motivations for visiting, with $24 \%$ wanting to share the outdoors with family and friends, $14 \%$ wanting to be close to nature, and $12 \%$ indicating the desire to experience tranquility.

These motivations also describe cognitive, visual, and social sensory states. The primary motivation expressed through hashtags in social media was the cognitive motivation of experiencing a sense of exploration (36\%). Visitors intending to experience a sense of exploration expect novel landscape views and auditory sensations, interactive learning with "sensescape" elements both tangible and intangible such as rocky terrain or different air pressure, and fewer interactions with other visitors (Bruce et al. 2015; Buzova et al. 2021; Dunne 2018). Experiencing a sense of exploration involves social and cognitive processes that include reflecting on public land value and feeling present in an authentic "nature space." Some examples of the hashtags used to identify the motivation to experience a sense of exploration are \#adventure, \#explorenevada, \#greatoutdoors, and \#neverstopexploring.

\section{$\underline{\text { Visitor Activities }}$}

Visitor activities performed on-site during the visit can become an embodied manifestation of their values and motivations, acted upon and in exchange with the sensescape. The visitor selects the activities to perform based on the desired sensory experience and their cognitive associations with the particular activity. While each activity selected to perform on-site represents a physical act, various 
sensory experiences occur within the visitor, including visual, auditory, tactile, olfactory, physical, social, and taste sensations.

Across all four study sites, the most popular activities identified in the survey are hiking $(87 \%)$, wildlife observation (75\%), photography $(63 \%)$, self-guided tours (58\%), and bird watching (47\%). Visitors to the Desert National Wildlife Refuge Complex enjoy these activities in higher numbers than at the Spring Mountains NRA. The Spring Mountains NRA has a high number of respondents who also participate in camping $(62 \%)$, exercise $(57 \%)$, and picnicking $(57 \%)$. While the proportion of visitors engaging in these activities varies site to site, these activities appear to be enjoyed consistently by visitors across all four study sites (Table 8).

\begin{tabular}{|c|c|c|c|c|c|c|c|c|}
\hline \multicolumn{9}{|c|}{ Table 8: Visitor Activities Reported in Survey Responses } \\
\hline 10 & 20 & 30 & 40 & 50 & 60 & 80 & 90 & 100 \\
\hline \multicolumn{9}{|c|}{ Percent of Respondents } \\
\hline & & & \multicolumn{2}{|c|}{$\begin{array}{c}\text { Desert NWR } \\
\text { Complex } \\
N=96\end{array}$} & \multicolumn{2}{|c|}{$\begin{array}{c}\text { Spring Mountains } \\
\text { NRA } \\
N=94\end{array}$} & \multicolumn{2}{|c|}{$\begin{array}{l}\text { All Sites } \\
\text { Combined } \\
N=190\end{array}$} \\
\hline $\begin{array}{l}\text { Sensory } \\
\text { Category }\end{array}$ & \multicolumn{2}{|c|}{ Activity } & $n$ & $\%$ & $n$ & $\%$ & $n$ & $\%$ \\
\hline Physical & \multicolumn{2}{|r|}{ Hiking } & 72 & $75 \%$ & 92 & $98 \%$ & 164 & $87 \%$ \\
\hline Visual & & $\begin{array}{r}\text { Wildlife } \\
\text { bservation }\end{array}$ & 77 & $80 \%$ & 65 & $69 \%$ & 142 & $75 \%$ \\
\hline Visual & & notography & 64 & $67 \%$ & 55 & $59 \%$ & 119 & $63 \%$ \\
\hline Physical/Visual & Self-G & uided Tour & 75 & $78 \%$ & 36 & $38 \%$ & 111 & $58 \%$ \\
\hline Visual & & rdwatching & 63 & $66 \%$ & 24 & $26 \%$ & 87 & $47 \%$ \\
\hline Physical & & Exercise & 33 & $34 \%$ & 54 & $57 \%$ & 87 & $46 \%$ \\
\hline Tactile/Taste & & Picnicking & 21 & $22 \%$ & 54 & $57 \%$ & 75 & $40 \%$ \\
\hline Physical/Tactile & & Camping & 16 & $17 \%$ & 58 & $62 \%$ & 74 & $40 \%$ \\
\hline Visual/Tactile & & Plant ID & 35 & $36 \%$ & 20 & $21 \%$ & 55 & $29 \%$ \\
\hline
\end{tabular}


While many of the sensory categories associated with activities are embodied or performed physically through the act of viewing, hearing, touching, smelling, and tasting, the chart above demonstrates the way the senses interconnect with each other during each activity. Many of these activities also feature social, cognitive, and emotional elements that vary by visitor. For example, foraging for wild foods may ultimately be a taste experience. However, the visitor must cognitively select a particular plant, identify a particular plant through sight and smell, and touch it to examine it before ultimately tasting it. Therefore, while each activity has a primary sensory function, they engage multiple senses simultaneously.

Across all four sites, $28 \%$ of hashtags identified in this sample described visitor activities (Table 9). These hashtags identified photography as the most frequently described activity ( $28 \%)$, followed by hiking (16\%), wildlife observation (10\%), and birdwatching (10\%). Hashtags analyzed for activity preference also indicated the need to expand the activity options beyond the survey scope to include backcountry/off-road auto tour (6\%), night recreation/stargazing (4\%), rock climbing (2\%), and mountain biking (1\%). These themes represent known visitor activities and may identify opportunities for engagement with specific visitors demonstrating expansion of site use for specialized recreation. Some of these hashtags describing activities include \#birdwatching, \#climbingmountains, \#hikingtrails, and \#summercamping. 


\begin{tabular}{|c|c|c|c|c|c|c|c|c|}
\hline \multicolumn{9}{|c|}{ Color Key } \\
\hline 10 & 20 & 30 & 40 & 50 & 60 & 80 & 90 & 100 \\
\hline \multicolumn{9}{|c|}{ Percent of Respondents } \\
\hline & & & \multicolumn{2}{|c|}{$\begin{array}{c}\text { Desert NWRC } \\
\quad N=740\end{array}$} & \multicolumn{2}{|c|}{$\begin{array}{c}\text { Spring Mountains } \\
\text { NRA } \\
\text { N=277 }\end{array}$} & \multicolumn{2}{|c|}{$\begin{array}{l}\text { All Sites } \\
\text { Combined } \\
\mathrm{N}=1017\end{array}$} \\
\hline $\begin{array}{l}\text { Sensory } \\
\text { Category }\end{array}$ & \multicolumn{2}{|c|}{ Activity } & $n$ & $\%$ & $n$ & $\%$ & $n$ & $\%$ \\
\hline Visual & \multicolumn{2}{|c|}{ Photography } & 201 & $27 \%$ & 83 & $30 \%$ & 284 & $28 \%$ \\
\hline Physical & \multicolumn{2}{|r|}{ Hiking } & 80 & $11 \%$ & 83 & $30 \%$ & 163 & $16 \%$ \\
\hline Visual & \multicolumn{2}{|c|}{ Wildlife Observation } & 80 & $11 \%$ & 22 & $8 \%$ & 102 & $10 \%$ \\
\hline Visual/Tactile & \multicolumn{2}{|c|}{ Birdwatching } & 103 & $14 \%$ & 2 & $1 \%$ & 105 & $10 \%$ \\
\hline Visual & \multicolumn{2}{|c|}{ Plant Identification } & 68 & $9 \%$ & 6 & $2 \%$ & 74 & $7 \%$ \\
\hline Visual & & Auto Tour & 53 & $7 \%$ & 4 & $1 \%$ & 57 & $6 \%$ \\
\hline Physical & & Camping & 36 & $5 \%$ & 14 & $5 \%$ & 50 & $5 \%$ \\
\hline Visual & Night & $\begin{array}{l}\text { Secreation/ } \\
\text { Stargazing }\end{array}$ & 34 & $5 \%$ & 10 & $4 \%$ & 44 & $4 \%$ \\
\hline Physical & & Exercise & 16 & $2 \%$ & 14 & $5 \%$ & 30 & $3 \%$ \\
\hline \begin{tabular}{|l} 
Physical/ \\
Tactile \\
\end{tabular} & Ro & k Climbing & 2 & $0 \%$ & 21 & $8 \%$ & 23 & $2 \%$ \\
\hline $\begin{array}{l}\text { Physicall } \\
\text { Tactile }\end{array}$ & & Fishing & 12 & $2 \%$ & 0 & $0 \%$ & 12 & $1 \%$ \\
\hline Physical & & Biking & 4 & $1 \%$ & 6 & $2 \%$ & 10 & $1 \%$ \\
\hline
\end{tabular}

While these activities are not exclusively visual, physical, and tactile, the visitor's experience becomes embodied while on site. These results show that while the multisensory experience of the visitor becomes more embodied as they interact with site specific features, a multitude of sensory experiences takes place within the visitor to construct the specific sensory experience that motivated their intention to visit. Reactivation of the sensory cycle occurs as they recover from their physical exertion of camping or rock climbing, reflect on their sensory experience, and summarize their visit's overall perceptions through a net-positive 
or net-negative evaluation. Often, visitors utilize social media posts or social conversations to describe this evaluation. The following section presents an indepth discussion of these results in conversation with the broader literature on sensory experiences in protected areas and nature-based tourist sites in general. 


\section{Discussion}

The results presented in this paper demonstrate the complexity of the visitor's multisensory experience to protected areas in southern Nevada. Before arriving on-site, visitors develop sensory expectations through reflecting on their values and identifying sensory motivations such as viewing scenic beauty and experiencing a sense of exploration. During their visit, they choose activities to embody their values and motivations and attain their sensory goals with activities such as wildlife viewing, photography, and hiking. After their time on-site, visitors reflect on their experience and recreate the sensory journey with the use of sensory artifacts like photographs, reviews, and social media posts, where they can further articulate the multisensory journey. The inherent multisensory experiences visitors have in these locations are complex, embodied, and deeply embedded in the meaning visitors create before, during, and after their trip, facilitating a unique attachment to these places (Qiu et al. 2021). Their emotional attachment to a place can influence the visitor's behavior beyond the site, evident in responsible and sustainable environmental behavior and conservation advocacy (Brehm 2012). Understanding these cognitive and internal processes experienced by the visitor can motivate land managers to intentionally create meaningful experiences to present to tourists and excursionists (Brehm 2012; Degnen 2016; Katzenholtz et al. 2020). The following sections describe the complexity of the sensory experience and the sensory cycle of visitor experiences before, during, and after the visit. 


\section{Sensory Complexity}

The sensory experience of visitors is complex and meaningful. Each visitor's values, motivations, and activities reflect a compound sensory experience that is simultaneously cognitive and embodied through their thoughts, emotions, and actions (Buzova et al. 2021; Qiu et al. 2018). For example, $63 \%$ of visitors participate in photography during their visit. Photography is a primarily visual activity; it is also tactile (holding the camera or smartphone, touching the button or screen to capture the image), cognitive (framing and considering the best photographic composition, photographing meaningful landscapes or wildlife, photographing interpretive panels, reflecting on the visit after the fact using photos to elicit memory and sensation), and even social (photographing social groups, taking selfies, and sharing photos to social media or through text messages). While each factor contributes a primary sensation, the underlying meaning assigned by the visitor through cultural, social, and individual means ensures that the visitor's sensory experience is dynamic and individual. This complexity contributes to the visitor's attachment to specific places, primarily through repeat visitation (Qiu et al. 2018).

Visitors who return to a site may seek to recreate previous sensory experiences (Bruce et al. 2015). This recreation occurs through revisiting beloved trails, landmarks, viewpoints, and campgrounds to perform similar activities as on previous visits. $87 \%$ of visitors surveyed report more than 5 visits to these sites, where repeat visitation contributes to the intensification of sensory experiences. Visitors will challenge themselves to hike a more strenuous trail, camp in a more 
rustic environment, or spend more time reading interpretive panels for deeper learning (Fix et al. 2013). This intensification contributes to repeating the liminal experience of the visitor, so upon their return the visitor feels refreshed and invigorated (Graburn 1989; Urry 1992). The visitor embarks on a cyclical sensory journey through repeat visitation and the recreation of previous multisensory experiences.

\section{The Sensory Cycle}

The sensory experience of visitors is cyclical and non-linear, relating to the visit stage. While preparing and planning to visit a site, visitors may experience anticipation and draw on their values and memories to construct their expectations for their visit. Construction of expectations is evident in visitor values and motivations, where $94 \%$ of visitors wanted to be close to nature, $82 \%$ hoped to experience tranquility, and $79 \%$ agreed that their time on-site deepened their appreciation for public lands. These motivations involve cognitive, emotional, and social factors as visitors decide when to plan their time on-site, what to do, and with whom. They may draw on memories of past experiences to avoid negative experiences associated with weather, poor preparation, or encounters with crowds. They may also identify goals for their visit to meet specific sensory needs, planning their activities to achieve specific physical, visual, or other sensory objectives through itineraries.

During the visit, sensory experiences become embodied, encompassing the five physical senses (sight, sound, smell, taste, touch) and more holistic body 
processes, such as the release of endorphins through exercise (Franco et al. 2017). For example, $87 \%$ of visitors list hiking as a primary activity during their time on site. Hiking involves all of the physical senses to some degree, engaging visual, auditory, tactile, and olfactory senses in addition to releasing endorphins in physically or cognitively challenging terrain. This activity also involves emotional, cognitive, and social factors, as the visitor's mental and emotional processes interact with the physical sensations in situ. They may converse with friends or others they encounter on the trail or feel a sense of accomplishment after achieving a difficult goal, triggering an emotional response. This phase of the visit is the distinct liminal space they sought- where not every factor of their visit is within their control. In natural areas like wildlife refuges and national recreation areas, weather conditions, wildlife availability, encounters with other visitors, and technical issues with transportation or other equipment will ultimately dictate the journey's outcome. These unknown factors further contribute to the cognitive experience of visitors.

After the visit, the visitor recalls various sensory experiences and synthesizes these sensations, which may distill into an emotional expression (i.e., "It was amazing!") or simply a positive or negative memory. Similarly, the reduction of these sensory experiences into "positive" or "negative" influences the visitor's future visit intention (Qiu et al. 2018), personal values, and perceptions of conservation objectives. For example, $93 \%$ of visitors agreed or strongly agreed that they thought about their connection with nature during their visit. Additionally, $82 \%$ of visitors agreed or strongly agreed that they reflected on their values during their time on site. These reflections influence the visitor's intention to revisit and 
may demonstrate pro-environmental behavior. Post-visit reflections may also encourage visitors to create and share impressions and sensory artifacts from the trip, such as photographs, unique rocks, fish or game harvested on-site, or pressed flowers. These sensory artifacts serve as a tool for eliciting emotion, further embedding the visitor's sense of place attachment to the object and sensescape from which it came (Rakic and Chambers 2011; Urry 1992). Figure 1 illustrates the stages of the sensory cycle.

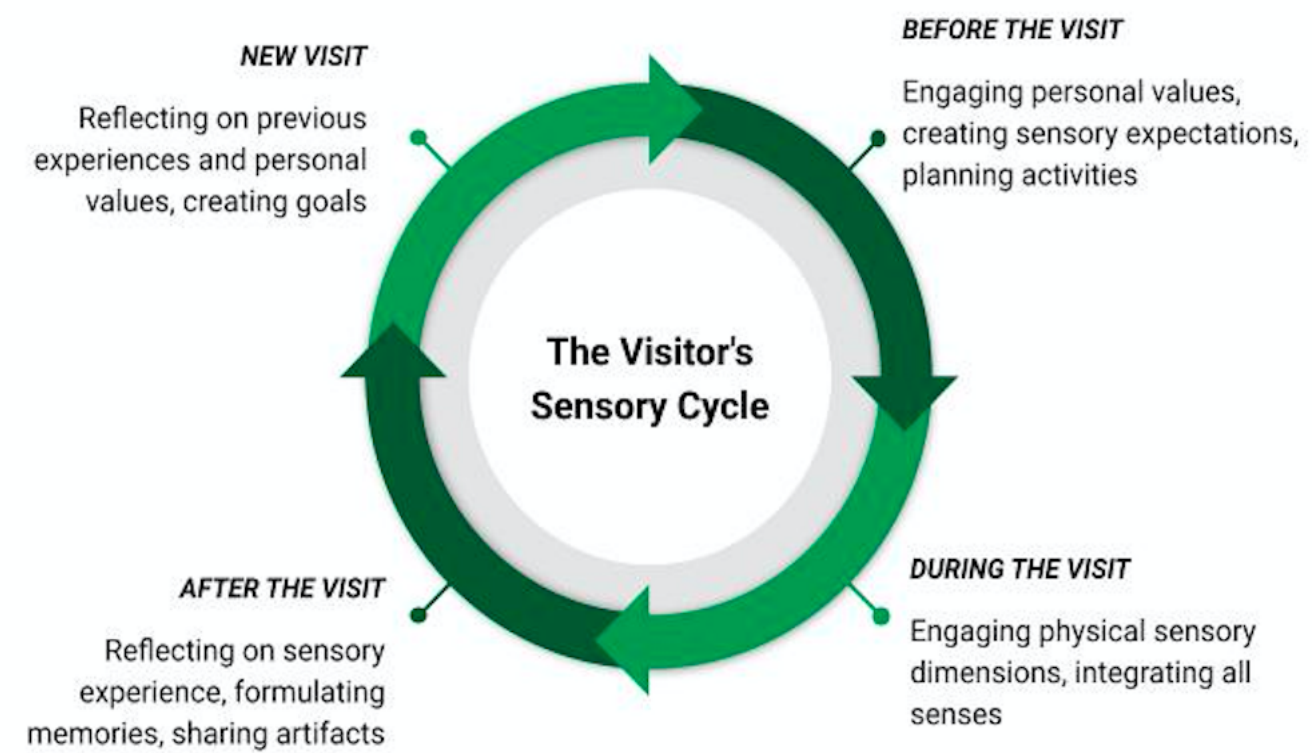

Figure 1: The Visitor's Sensory Cycle. Each stage of the visit engages certain sensory dimensions and influences the other stages.

Lasting emotional impressions influence future visit intentions (Katzenholtz et al. 2020), which begins the sensory cycle anew through reflecting on the experience and creating personal goals for future visits. This process- where the complex sensory experience of the visitor cycles from cognitive to embodied in physical activity and back to cognitive- builds over time as the visitor engages in similar experiences and creates emotional ties to places like the four study sites. 
This process of seeking, experiencing, and reflecting on the sensory journey facilitates place attachment and contributes to responsible environmental behavior (Vaske and Kobrin 2001).

\section{Management Implications}

Managers of protected areas monitor visitor use patterns to inform various short- and long-term decisions. However, understanding visitor behavior as informed by complex sensory experiences is valuable for meeting many management goals. As stated above, the sensory experiences of visitors are complex and cyclical. Visitors experience unique sensations at each stage of the visit and seek specific sensations while on site.

Interpretive activities, programming, and marketing materials that can enhance these sensory journeys through targeted initiatives can occur during typical planning activities on site. For example, describing protected areas as locations where visitors can "view scenic beauty," "smell fresh air," or "hear and touch a cascading waterfall" can embed sensory expectations into the visitor's mind in all phases of the visit. While on site, interpretation and programming can orient the visitor to multisensory experiences by encouraging them to see, hear, touch, and smell environmental elements. Managers and site employees can then engage visitors after their visit by encouraging them to share photos on social media, connect with partner organizations for volunteer opportunities, and share information about policies that may impact the protected area. Qualifying these experiences as "sensory itineraries" intended to engage the senses can attract 
new visitors, encourage repeat visitation (Buzova et al. 2021), more responsible visitor use (Brehm et al. 2012; Vaske and Kobrin 2001), and support for protective initiatives (Tanner et al. 2008). Site managers can thus leverage these sensory journeys to facilitate place attachment within visitors to protected areas, influencing visitor behavior and promoting protected area goals of public use, conservation, and stewardship (Qiu et al. 2018).

An existing example of how this interpretation can contribute to a visitor's sensory expectations is the "welcome statement" interpretive panel at the Desert National Wildlife Refuge's Corn Creek Visitor Center. Co-created with the Indigenous Nuwu/Nuwuvi working group composed of tribally designated representatives from seven Tribal Nations, the statement orients visitors to the site by "opening their senses" for their journey through the refuge (Jeremy Spoon, personal communication, October 29, 2021). The welcome statement reads:

"Welcome to Pakonapah. At the beginning of time, the Creator breathed life into this world, carefully placing and interconnecting everything-springs, plants, animals, mountains, rocks, sky, and climate. Nuwu/Nuwuvi (Southern Paiute and Chemehuevi) were given the responsibility to care for and interact with this delicate cultural landscape to ensure its continued existence. As you look, listen, smell and touch, you will feel the power of the Creator, hear the echoes of our songs, and experience the presence of our ancestors and the spirits who watch over our land. Collectively, Nuwu/Nuwuvi and the U.S. Fish and Wildlife Service strive to keep Pakonapah in balance for future generations. We share this special gift with everyone to respect, admire, and enjoy."

-Nuwuvi Working Group, Welcome Statement at the Corn Creek Visitor Center, Desert National Wildlife Refuge 
This statement incorporates sensory terminology as part of imploring the visitor to consider the broader implications of their behavior while touring the siteemphasizing the site's importance to the Indigenous groups affiliated with the site and the shared responsibility of its stewardship with the government agency and the public. While this statement is a permanent interpretive panel at this site, this type of specialized interpretation that intends to engage the visitor's multisensory experience would also be effective as temporary interpretation, or as part of site programming.

Public land managers can similarly consider the benefits of incorporating Indigenous perspectives into site interpretation to create depth and context for the visitor's sensory experience. Indigenous groups with cultural ties to specific protected areas can contribute to ethnographic research in planning for natural/cultural resource management, interpretation, and public outreach. This participation need not be limited to mandated consultation activities but can also serve to establish rapport between protected area managers and tribal governments, create co-management praxis with affiliated tribal representatives (Spoon and Arnold 2012), and help to engage underrepresented protected area visitors and outdoor recreationists through creating visible artifacts of these relationships in the form of permanent or temporary interpretive elements and environmental education programming.

Protected area managers should also note that the visitor's experience does not begin and end at the boundary of the protected area. As this study demonstrates, the visitor's experience begins long before they arrive, and 
continues long after they depart. Therefore, those interested in enhancing visitor engagement, increasing environmentally responsible behavior, and leveraging varying levels of place attachment should consider ways to connect with visitors outside of the site visit. This study also shows that an effective way to connect with these visitors during each phase of the visit is using social media. Through developing a presence on social media and managing this presence as if it were a perpetual and meaningful connection with visitors, site managers can disseminate information about the protected area, help to build active relationships with repeat visitors, contribute to virtual community building, and recruit visitor support for activities from volunteer events to conservation initiatives. Building these connections with visitors on social media may also be a more effective way of reaching younger, more diverse audiences than traditional outreach methods like newsletters through partner organizations.

While social media research does have its limitations, such as lack of demographic information for its users, it is an emerging and important source for user-generated data that can provide deep insight into the visitor experience of protected area tourists. Many environmental scientists are utilizing social media to track visitor movements through protected areas (Hamstead et al. 2017; Tenkanen et al. 2017; Wilkins et al. 2020), understand ecosystem effects of tourism (Arslan and Örücü 2020; Sinclair et al. 2018), and create longitudinal understanding of attitudes toward conservation action (Miller et al. 2019; Wu et al. 2018) or specific wildlife species (Edwards et al. 2021; Monkman et al. 2018). These diverse research avenues demonstrate the versatility of social media research as 
applicable to protected areas like wildlife refuges and national recreation areas. A robust understanding of the possibilities of social media research can lead protected area managers to seek to understand their publics in new ways, which can impact planning activities for visitor use, outdoor recreation, conservation, and stewardship in both the short and long term.

Social media also has beneficial implications for connecting with nontraditional protected area visitors. Researchers and public land managers alike have attempted to engage more diverse public land visitors to visit, recreate, and develop pro-environmental attitudes as the demographic makeup of the United States becomes increasingly racially and ethnically diverse (Gaither et al. 2015; Winter et al. 2020). Survey respondents in this study identified themselves as largely white, well educated, and earning above-average incomes. While the demographics of the social media users identified in this study are unknown, the most recent report by the Pew Research Center (2021) notes that social media users are generally under age 35 , predominantly non-white, and represent a broad spectrum of educational backgrounds and incomes. Therefore, engaging social media users for outreach purposes can potentially create meaningful connections between these non-traditional visitors that are well-represented on social media and the protected areas they frequent.

Furthermore, outdoor recreationists of all backgrounds utilize social media to connect with each other in these digital community spaces. An example of this is the viral popularity of "Black Birders Week" during the summer of 2020, an event catalyzed by a racially motivated conflict between birdwatchers in Central Park, 
New York City (Mock 2020). The week-long event employed the hashtag \#blackbirdersweek to create a digital community platform for Black birdwatchers to connect through social media and in person. The event, repeated in 2021, articulated the unique challenges of Black outdoor recreationists and aimed to demonstrate the diversity of outdoor enthusiasts not just to the general public, but to younger generations who may have interest in birding or other outdoor recreation activities (Mock 2020). The 2021 event also featured partnerships with universities, non-profit organizations, and federal agencies- including the U.S. Fish and Wildlife Service and National Oceanic and Atmospheric Association (https://www.blackafinstem.com/bbw2021schedule). Visitors thus use social media to find "hyper-local" niche communities (Hochman 2018), join local outdoor recreation groups, connect with community members both local and remote, and learn about site-specific itineraries through their digital social groups. Social media is an increasingly important location for these non-traditional protected area visitors to create safe spaces and meaningful experiences on public lands. 


\section{Conclusion}

This study demonstrated the complex and meaningful sensory journey of visitors to protected areas in southern Nevada. It found that embedded in visitor values, motivations, and activities are complex multisensory experiences, inextricable from one another and mutually acting upon the visitor and landscape. These factors simultaneously derive cognitive, emotional, social, and physical sensory activation as the visitor moves through the visit stages and the surrounding sensescape. In each stage, protected area visitors create expectations, adjust motivations, plan activities, interact with environmental features in situ, and reflect on their experiences cognitively with the use of emotional artifacts like photographs. Each section articulated the way that these multisensory experiences are inherently present in protected area tourism, and how they contribute to feelings of place attachment and responsible environmental behavior. Further, understanding these inherent experiences of visitors prepares protected area managers making meaningful planning decisions for meeting visitation, recreation, and conservation objectives.

As with many protected areas, these sites are prime locations for visitors to develop meaningful place attachments. While the study of place attachment, like multisensory tourist experiences, is broad and multidisciplinary, scholars agree that place attachment is a central component of responsible environmental behavior (Agapito et al. 2017; Brehm 2012; Katzenholtz et al. 2020; Ramkissoon 2012; Tonge et al. 2015). Therefore, these natural spaces inherently offer a multisensory experience for visitors and contribute to pro-environmental activities 
such as volunteering, campaigning to preserve protected areas, and support for protected area management objectives.

While much of the internal experience of visitors to protected areas cannot be controlled or planned for, land managers can consider these multisensory experiences important locations for developing meaningful interactions with visitors through interpretation and programming. Intentionally designing "sensescape" experiences may also contribute to planning new trail systems, campgrounds, and other permanent and temporary features. Marketing these locations as "sensory itineraries" (Buzova et al. 2021) and emphasizing the sensory journey may contribute to high-quality visitor experiences, where the visitor is engaged, responsible, and accountable for their behavior in protected areas. Through the activation of the holistic senses within the visitor, visitors can make impactful memories, thus creating lifetime advocates who care about the future of protected areas and are willing to align their values and behavior accordingly. 


\section{$\underline{\text { References }}$}

Agapito, Dora, Julio Mendes, and Patricia Valle. 2013. "Exploring the Conceptualization of the Sensory Dimension of Tourist Experiences." Journal of Destination Marketing \& Management 2(2): 62-73.

Agapito, Dora, Patrícia Pinto, and Júlio Mendes. 2017. "Tourists' Memories, Sensory Impressions and Loyalty: In Loco and Post-visit Study in Southwest Portugal." Tourism Management (1982) 58: 108-18.

Agapito, Dora, Patrícia Valle, and Júlio Mendes. 2014. "The Sensory Dimension of Tourist Experiences: Capturing Meaningful Sensory-informed Themes in Southwest Portugal." Tourism Management (1982) 42: 224-37.

Arslan, E. Seda, and Ömer K Örücü. 2020. "MaxEnt Modelling of the Potential Distribution Areas of Cultural Ecosystem Services Using Social Media Data and GIS." Environment, Development and Sustainability 23 (2): 2655-667.

Bernard, H. Russel. 2006. Research Methods in Anthropology. $4^{\text {th }}$ Edition. Landam, MD: AltaMira.

Brehm, J. M. 2012. "Environmental Concern: Examining the Role of Place Meaning and Place Attachment." Society \& Natural Resources. 26 (5): 1538.

Brooks, Jeffrey J. and Robert Massengale. 2011. "Planning for People? An Evaluation of Objectives for Managing Visitors at Wildlife Refuges in the United States." USDA Forest Service Proceedings RMRS-P-64. U.S.D.A. Forest Service.

Bruce, Neil, Jenna Condie, Victoria Henshaw, and Sarah R Payne. 2017. "Analysing Olfactory and Auditory Sensescapes in English Cities: Sensory Expectation and Urban Environmental Perception." Ambiances (En Ligne), 2017-08-31.

Comay, Laura B., R. Eliot Crafton, Carol Hardy Vincent, and Katie Hoover. 2018. "Federal Land Designations: A Brief Guide." Congressional Research Service R45340: www.crs.gov. 
Conti, Eugenio, and Maria Lexhagen. 2020. "Instagramming Nature-based Tourism Experiences: A Netnographic Study of Online Photography and Value Creation." Tourism Management Perspectives 34: 100650.

Dai, Tianchen, and Xing Zheng. 2021. "Understanding How Multi-sensory Spatial Experience Influences Atmosphere, Affective City Image and Behavioural Intention." Environmental Impact Assessment Review 89: 106595.

Degnen, Cathrine. 2016. "Socialising Place Attachment: Place, Social Memory and Embodied Affordances." Ageing and Society 36 (8): 1645-667.

Desjarlais, Robert, and C. Jason Throop. 2011. "Phenomenological Approaches in Anthropology." Annual Review of Anthropology 40 (1): 87-102.

Dietsch, A. M., Sexton, N. R., Lyon, K. M., Hartel, C. M., \& Mengak, L. F. 2019. National Wildlife Refuge Visitor Survey: 2018 Results for Desert National Wildlife Refuge. Columbus, $\mathrm{OH}$ : The Ohio State University, School of Environment and Natural Resources.

Di Minin, Enrico, Henrikki Tenkanen, and Tuuli Toivonen. 2015. "Prospects and Challenges for Social Media Data in Conservation Science." Frontiers in Environmental Science Vol 3.

Driver, B.L. and Don Burns. 2008. "Implementing OFM on Public Nature-Based Recreation and Related Amenity Resources." In Managing to Optimize the Beneficial Outcomes of Recreation, ed. B.L. Driver. Venture Publishing, Inc.

Edwards, Thomas, Christopher B Jones, Sarah E Perkins, and Padraig Corcoran. 2021. "Passive Citizen Science: The Role of Social Media in Wildlife Observations." PloS One 16 (8): E0255416.

Ervin, Alexander M. 2008. Applied Anthropology: Tools and Perspectives for Contemporary Practice. 2nd Edition. Boston: Pearson.

Fix, Peter J., Joshua Carroll, and Andrew M. Harrington. 2013. "Visitor experiences across recreation settings: a management or measurement issue?" Journal of Outdoor Recreation and Tourism 3-4: 28-35. 
Franco, Lara S., Danielle F. Shanahan, and Richard A. Fuller. 2017. "A Review of the Benefits of Nature Experiences: More Than Meets the Eye." International Journal of Environmental Research and Public Health 14 (8): 864.

Gaither, Cassandra Johnson, Nina S. Roberts, Kristin L. Hanula and the United States Forest Service. Southern Research Station, Issuing Body. 2015. "Visitor Diversity through the Recreation Manager Lens: Comparing Forest Service Regions 8 (U.S. South) and 5 (California)." General Technical Report SRS; 205. Asheville, NC: United States Department of Agriculture, Forest Service, Research \& Development, Southern Research Station.

Goggin, C. Louise, Patricia M. Please, Malcolm J. Ridges, Charles A. Booth, Geoffrey R. Simpson, Richard Green, and John F Leys. 2017. "Connecting with Country in Mungo National Park, Australia: A Case Study to Measure the Emotional Dimension of Experience and Place Attachment." Local Environment 22 (10): 1217-236.

Graburn, Nelson H.H. 1983. "The Anthropology of Tourism." Annals of Tourism Research 10(1) : 9-33.

Graburn, Nelson H. H. 1989. "Chapter 1- Tourism, the Sacred Journey." in Hosts and Guests: The Anthropology of Tourism. 2nd ed. Ed. Valene L. Smith. Philadelphia: University of Pennsylvania Press.

Hamstead, Zoé A., David Fisher, Rositsa T. llieva, Spencer A. Wood, Timon McPhearson and Peleg Kremer. 2018. "Geolocated social media as a rapid indicator of park visitation and equitable park access." Computers, Environment and Urban Systems 72: 38-50.

Hickman Dunne, Jo. 2019. "Experiencing the Outdoors: Embodied Encounters in the Outward Bound Trust." The Geographical Journal 185 (3): 279-91.

Hochman, Nadav. 2018. "From site-specificity to hyper-locality: performances of place in social media." In The SAGE Handbook of social media research methods (pp. 367-385). SAGE Publications Ltd. https://www-doiorg.proxy.lib.pdx.edu/ 10.4135/9781473983847

Howes, David. 2019. "Multisensory Anthropology." Annual Review of Anthropology 48 (1): 17-28. 
Jorgensen, Bradley S., and Richard C Stedman. 2001. "Sense of place as an attitude: Lakeshore owners' attitudes toward their properties." Journal of Environmental Psychology 21 (3): 233-48.

Kastenholz, Elisabeth, Carlos Peixeira Marques, and Maria João Carneiro. 2020. "Place Attachment through Sensory-rich, Emotion-generating Place Experiences in Rural Tourism." Journal of Destination Marketing \& Management 17: 100455.

Kil, Namyun, Stephen M. Holland, Taylor V. Stein, and Yong Jae Ko. 2012. "Place Attachment as a Mediator of the Relationship between Nature based Recreation Benefits and Future Visit Intentions." Journal of Sustainable Tourism 20(4): 603-26.

Kyle, Gerard and Garry Chick. 2007. "The Social Construction of a Sense of Place." Leisure Sciences 29 (3): 209-25.

Laestadius, Linnea. 2016. "Instagram." In The SAGE Handbook of social media research methods (pp. 573-592). SAGE Publications Ltd. https://www-doi org.proxy.lib.pdx.edu/10.4135/9781473983847

Larsen, Jonas, and John Urry. 2011. "Gazing and Performing." Environment and Planning. D, Society \& Space 29 (6): 1110-125.

Lin, Yi Hsien, and Tsung Hung Lee. 2020. "How Do Recreation Experiences Affect Visitors' Environmentally Responsible Behavior? Evidence from Recreationists Visiting Ancient Trails in Taiwan." Journal of Sustainable Tourism 28 (5): 705-26.

Low, Kelvin E.Y. 2012. "The Social Life of the Senses: Charting Directions." Sociology Compass 6 (3): 271-82.

Manning, Robert E. 2011. Studies in Outdoor Recreation. Corvallis: Oregon State University Press.

Meacci, Luca, and Giovanni Liberatore. 2018. "A Senses-based Model for Experiential Tourism." Tourism \& Management Studies 14 (4): 7-14. 
Mehraliyev, Fuad, Andrei P Kirilenko, and Youngjoon Choi. 2020. "From Measurement Scale to Sentiment Scale: Examining the Effect of Sensory Experiences on Online Review Rating Behavior." Tourism Management (1982) 79: 104096.

Mock, Jillian. 2020. "'Black birders week' promotes diversity and takes on racism in the outdoors." Audobon Magazine. June 1, 2020. https://www.audubon.org/news/black-birders-week-promotes-diversityand-takes-racism-outdoors

Monkman, Graham G, Michel J Kaiser, and Kieran Hyder. 2018. "Text and Data Mining of Social Media to Map Wildlife Recreation Activity." Biological Conservation 228: 89-99.

Monz, Christopher A., David N. Cole, Yu-Fai Leung, and Jeffrey L. Marion. 2010. "Sustaining visitor use in protected areas: future opportunities in recreation ecology research based on the USA experience." Environmental Management 45 (3): 551-562.

Moyle, Brent D., Pascal Scherrer, Erica Wilson, Rod Caldicott, and Noah Nielsen. 2017. "Assessing preferences of potential visitors for naturebased experiences in protected areas." Tourism Management 62: 29-41.

Pan, Steve, and Chris Ryan. 2009. "Tourism sense-making: The role of the senses and travel journalism." Journal of Travel \& Tourism Marketing 26 (7): 625-39.

Pew Research Center. 2021. "Social Media Use in 2021." Retrieved November 4, 2021. https://www.pewresearch.org/internet/2021/04/07/social-media-usein-2021/

Pink, Sarah. 2010. "The Future of Sensory Anthropology/the Anthropology of the Senses." Social Anthropology 18 (3): 331-33.

Quan-Haase, A. \& Sloan, L. 2016. Introduction to the handbook of social media research methods: goals, challenges and innovations. In The SAGE Handbook of social media research methods (pp. 1-9). SAGE Publications Ltd, https://www-doi-org.proxy.lib.pdx.edu/10.4135/9781473983847

Qiu, Mengyuan, Jie Zhang, Honglei Zhang, and Chunhui Zheng. 2018. "Is 
Looking Always More Important than Listening in Tourist Experience?" Journal of Travel \& Tourism Marketing 35 (7): 869-81.

Qiu, Mengyuan, Xin Jin, and Noel Scott. 2021. "Sensescapes and Attention Restoration in Nature-based Tourism: Evidence from China and Australia." Tourism Management Perspectives 39.

Rakić, Tijana, and Donna Chambers. 2012. "Rethinking the Consumption of Places." Annals of Tourism Research 39 (3): 1612-633.

Ramkissoon, H. 2012. "Place Attachment and Pro-environmental Behaviour in National Parks: The Development of a Conceptual Framework." Journal of Sustainable Tourism 20 (2): 257-76.

Rice, William L , Garrett C Hamilton, and Peter Newman. 2019. "Pungent Parks: Smell's Growing Relevance in Park Tourism." Journal of Tourism Futures 6 (2): 135-38.

Roberge, Jean-Michel. 2014. "Using data from online social networks in conservation science: which species engage people the most on Twitter?" Biodiversity Conservation 23: 715-726. https://doi.org/10.1007/s10531014-0629-2

Roggenbuck, Joseph W. 2000. "Facilitating high-quality visitor experiences at national wildlife refuges." in Fulton, David, Kristen C. Nelson, Dorothy $\mathrm{H}$. Anderson, David W. Lime (eds.) Human Dimensions of Natural Resource Management: Emerging Issues and Practical Applications. 2000, Feb 1-3; St. Paul, MN. BRD 2000-1. St. Paul, MN: Cooperative Park Studies Program, University of Minnesota, Department of Forest Resources: 126132.https://www.nrs.fs.fed.us/pubs/jrnl/2000/nc_2000_Bengston_006.pdf

Saldaña, Johnny. 2016. The Coding Manual for Qualitative Researchers. Los Angeles: SAGE Publications.

Schensul, Jean J. and Margaret D. LeCompte. 2013. Essential Ethnographic Methods. Lanham, Maryland: Alta Mira.

Schensul, Stephen L., Jean J. Schensul and Margaret D. LeCompte. 2013. "Mixed Methods Models, Measures and Case Examples." in Initiating Ethnographic Research: A Mixed Methods Approach. Lanham, Maryland: 
Alta Mira. Pp. 155-184.

Scott, Alister, Claudia Carter, Katrina Brown, and Vicki White. 2009. "'Seeing Is Not Everything': Exploring the Landscape Experiences of Different Publics." Landscape Research 34 (4): 397-424.

Sessions, Carrie, Spencer A. Wood, Sergey Rabotyagov, and David M. Fisher. 2016. "Measuring recreational visitation at U.S. National parks with crowdsourced photographs." Journal of Environmental Management 183(3): 703-711.

Sinclair, Michael, Andrea Ghermandi, and Albert M Sheela. 2018. "A Crowdsourced Valuation of Recreational Ecosystem Services Using Social Media Data: An Application to a Tropical Wetland in India." The Science of the Total Environment 642: 356-65.

Sloan, Luke, and Anabel Quan-Haase. 2017. The Sage Handbook of Social Media Research Methods. Thousand Oaks, CA: SAGE Publications.

Smith, Scott M. 2020. "Determining Sample Size: How to ensure you get the correct sample size." QualtricsXM. https://www.qualtrics.com/ebooksguides/determining-sample-size/?utm_lp=blog-sample-size-calc

Spoon, Jeremy. 2013. "Different Ways of Knowing, Shared Goals: Applied Sustainability Projects in the Himalayas and Great Basin." In Social Sustainability: A Multilevel Approach to Social Inclusion edited by J. Dillard, V. Dujon and E. Brennan. London: Routledge. Pp. 211-232.

Spoon, Jeremy and Richard Arnold. 2012. "Collaborative Research and Co Learning: Integrating Nuwuvi (Southern Paiute) Ecological Knowledge and Spirituality to Revitalize a Fragmented Land." Journal for the Study of Religion, Nature, and Culture 6 (4): 477-500.

Sukach, Chris. (n.d.) "Spring Mountains National Recreation Area- More Than a Backyard." U.S. Department of Agriculture, Forest Service. Accessed October 18, 2021. https://www.fs.usda.gov/detail/htnf/aboutforest/districts/?cid=fseprd875406.

Tanner, Randy J., Wayne A. Freimund, William T. Borrie and R. Neil Moisey. 2008. "A Meta-Study of the Values of Visitors to Four Protected Areas in 
the Western United States." Leisure Sciences 30 (5): 377-390. DOI: 10.1080/01490400802353026

Tenkanen, Henrikki, Di Minin, Enrico, Heikinheimo, Vuokko, Hausmann, Anna, Herbst, Marna, Kajala, Liisa, and Toivonen, Tuuli. 2017. "Instagram, Flickr, or Twitter: Assessing the Usability of Social Media Data for Visitor Monitoring in Protected Areas." Scientific Reports 7 (1): 17615-11.

Tonge, Joanna, Ryan, Maria M., Moore, Susan A., and Beckley, Lynnath E. 2015. "The Effect of Place Attachment on Pro-environment Behavioral Intentions of Visitors to Coastal Natural Area Tourist Destinations." Journal of Travel Research 54 (6): 730-43.

Tuan, Yi-Fu. 1979. "Space and Place: Humanistic Perspective." In: Gale S., Olsson G. (eds)Philosophy in Geography. Theory and Decision Library (An International Series in the Philosophy and Methodology of the Social and Behavioral Sciences), vol 20. Springer, Dordrecht. https://doi.org/10.1007/978-94-009-9394-5_19

Turner, Victor W. 1967. The Forest of Symbols : Aspects of Ndembu Ritual. Cornell Paperbacks. Ithaca, N.Y.: Cornell University Press.

Urry, John. 1992. "The Tourist Gaze and the `Environment'." Theory, Culture \& Society 9 (3): 1-26.

U.S. Census Bureau. Las Vegas Quick Facts. Census.gov

U.S. Department of Agriculture, Forest Service. n.d. "Managing the Land." U.S. Forest Service. Accessed June 20, 2021. https://www.fs.usda.gov/managing-land.

U.S. Department of Agriculture, Forest Service. FY 2016. Humboldt-Toiyabe NF Spring Mountains NRA: National Visitor Use Monitoring Results. https://apps.fs.usda.gov/nvum/results/A04117.aspx/FY2016

U.S. Department of the Interior. 2016. "America's Public Lands Explained." U.S. Department of the Interior Blog, September 29, 2021. https://www.doi.gov/blog/americas-public-lands-explained.

U.S. Department of the Interior, United States Fish and Wildlife Service. 2021. 
"Desert National Wildlife Range - Desert -U.S. Fish and Wildlife Service." U.S. Fish \& Wildlife Service. Accessed March 18, 2021. https://www.fws.gov/refuge/desert/.

U.S. Department of the Interior, United States Fish and Wildlife Service. 2021. USFWS -FWS Public Health Update. Accessed March 18, 2021. https://www.fws.gov/home/public-health-update.html

U.S. Department of the Interior, United States Fish and Wildlife Service. 2021. "About Us- U.S. Fish and Wildlife Service." U.S. Fish and Wildlife Service. Accessed June 20, 2021. https://www.fws.gov/help/about_us.html

U.S. Department of the Interior, United States Fish and Wildlife Service. 2020. "Partnerships-Desert - U.S. Fish and Wildlife Service." U.S. Fish \& Wildlife Service. Accessed June 21, 2021. https://www.fws.gov/refuge/Desert/what_we_do/partnerships.html

Vaske, Jerry J, and Katherine C Kobrin. 2001. "Place Attachment and Environmentally Responsible Behavior." The Journal of Environmental Education 32 (4): 16-21

Wang, Siyi. 2020. "Museum as a Sensory Space: A Discussion of Communication Effect of Multi-Senses in Taizhou Museum." Sustainability (Basel, Switzerland) 12 (7): 3061.

Wilkins, Emily J, Spencer A Wood, and Jordan W Smith. 2020. "Uses and Limitations of Social Media to Inform Visitor Use Management in Parks and Protected Areas: A Systematic Review." Environmental Management 67 (1): 120-32.

Winter, Patricia L, William D Crano, Tatiana Basanez, and Christopher S Lamb. 2020. "Equity in Access to Outdoor Recreation-Informing a Sustainable Future." Sustainability (Basel, Switzerland) 12 (1): 124.

Wood, Spencer A., Anne D. Guerry, Jessica M. Silver and Martin Lacayo. 2013. "Using social media to quantify nature-based tourism and recreation." Scientific Reports 3: 2976. DOI: 10.1038/srep02976.

Wu, Yinglin, Ling Xie, Shiang-Lin Huang, Ping Li, Zengwei Yuan, and Wenhua Liu. 2018. "Using Social Media to Strengthen Public Awareness of Wildlife 
Conservation." Ocean \& Coastal Management 153: 76-83. 
Appendix: Visitor Survey

Desert National Wildlife Refuge Complex and Spring Mountains National Recreation Area

\author{
Online Visitor Survey
}

\author{
Desert National Wildlife Refuge \\ Ash Meadows National Wildlife Refuge \\ Pahranagat National Wildlife Refuge \\ Spring Mountains National Recreation Area
}

\title{
Section 1: Visitor Demographics
}

Your answers to these questions will help us to know more about who visits national wildlife refuges. Answers will not be linked to any individual taking this survey.

01. I am: [] Male [ ] Female

$\begin{array}{llll}\text { 02. My age: } & \text { [ ] } 18-29 & \text { [ ] } 50-59 & \\ & \text { [] } 30-39 & \text { [ ] } 60-69 & \text { [ ] } 80 \text { or better } \\ & \text { [] } 40-49 & \text { [ ] } 70-79 & \end{array}$

03. What race or ethnicity do you consider yourself? (Mark all that apply.) Native
[ ] White, European descent
[ ] American Indian or Alaska

Paiute)

[] Hispanic, Latino/a [ ] Nuwu/Nuwuvi (Southern

[ ] Black or African descent

[] Asian

[ ] Middle Eastern or North African

[ ] Native Hawaiian or Pacific Islander

or Newe (Western

Shoshone)

[]

[ ] Other

04. Where do you live?

[] United States

[ ] ZIP code

[ ] International Visitor

[ ] Country

05. What is your highest education level? (Mark only one.)
[] $\mathrm{K}-8$
[ ] $9-12$
[] Some College
[] Bachelor's Degree
[ ] Graduate School

06. Which of the following best describes your current employment status? 
(Please mark just one.) to Work

[] Employed Full-Time [] Unemployed [] Retired

[] Employed Part-Time [] Homemaker/Caregiver [] Disabled/Unable

[] Self-Employed [ ] Student [] Other

07. What was your approximate income before taxes last year? (Mark only one.) $\$ 149,999$

[] Less than $\$ 10,000$ [] $\$ 35,000-\$ 49,999$ [ ] $\$ 100,000$ -
[] $\$ 10,000-\$ 24,999$
[] $\$ 50,000-\$ 74,999$
[ ] $\$ 25,000-\$ 34,999$
[ ] $\$ 75,000-\$ 99,999$
[ ] $\$ 150,000$ or more

\section{Section 2: Visitor Motivations}

08. Please indicate which site(s) you have visited (refuge complex only):

[ ] Desert National Wildlife Refuge

[ ] Ash Meadows National Wildlife Refuge

[ ] Pahranagat National Wildlife Refuge

09. How did you hear about the Desert NWRC/Spring Mountains NRA?

[ ] Personal knowledge or previous visit

[] Word-of-mouth

[ ] Refuge Website or brochure

[ ] Travel Website or brochure

[] Tourist information

[] Social Media

[] Google, Google Maps

[] Facebook

[] Instagram

[ ] Other

[] Other:

10. Including your most recent visit, which activities did you participate in during the past 12 months at this location? (Mark all that apply.)

\begin{tabular}{|c|c|c|}
\hline $\begin{array}{l}\text { [] Wildlife Observation } \\
\text { [ ] Bird Watching }\end{array}$ & $\begin{array}{l}\text { [] Hiking } \\
\text { [] Exercise }\end{array}$ & $\begin{array}{l}\text { [] Volunteering } \\
\text { [] Environmental }\end{array}$ \\
\hline Education & & \\
\hline [] Photography & [ ] Auto tour & [] Viewing Exhibits \\
\hline $\begin{array}{l}\text { [] ] Hunting } \\
\text { workshop }\end{array}$ & [] Boating & [] Live program or \\
\hline [] Fishing & [] Picnicking & [] Refuge Event \\
\hline
\end{tabular}



panels

[ ] Foraging (berries, nuts, etc.) [] Camping [ ] Reading trail
[] Plant Identification
[] Snow Play
[ ] Archaeology
[ ] Self-Guided Tour
[] Guided tour [] Other

11. What other motivations did you have for visiting this site?

(Mark all that apply.)

[] View scenic beauty

[ ] Be close to nature

Enjoy the sounds of nature

[] Experience tranquility

[] Share outdoors with family

[] Escape the heat

[] Share outdoors with friends

[] Enjoy the snow

[] Share photos on social media [] Experience a sense of exploration

[ ] Learn more about Nuwu/Nuwuvi/Newe (Southern Paiute and Western

Shoshone) or other local Native American groups

[ ] Learn more about environmental advocacy and stewardship

12. How long did you spend at the refuge during this visit?

Hours or Days

13. How did you travel to visit us at the refuge today?
[ ] Personal Vehicle
[] Motorcycle
[ ] Recreational Vehicle
[ ] Tour bus/van
[] Bicycle
[ ] Other:

14. How many times have you visited the refuge?

[ ] This was my first time

[] Between 1 and 5 times

[] Between 5 and 10 times

[ ] More than 10 times

15. Including this visit, during which seasons have you visited this refuge?

(Mark all that apply.)

[] Spring (March-May) [ ] Summer (June-August)

[] Fall (September- November) [] Winter (December-February)

16. Do you plan to return to this refuge, or another National Wildlife Refuge in the NWR,

Desert National Wildlife Refuge Complex (Desert NWR, Ash Meadows

Pahranagat NWR, Moapa NWR) within the next 12 months?

[ ] Yes, I live locally [ ] Maybe

[ ] Yes, on my next visit [] No 
17. What did you learn about wildlife refuges on your visit? (refuge complex only)

18. How are wildlife refuges different than other public lands? (refuge complex only)

\section{Section 3: Your Experience Today}

19. Did you explore the visitor center during your visit today? Yes No

If yes, what did you do at the Visitor Center? (Mark all that apply.)

[] Asked information of employees/volunteers

[ ] Attended a talk/video presentation

[ ] Viewed the exhibits and interpretation

[ ] Visited gift shop or bookstore

[ ] Viewed list of recent bird and wildlife sightings

[ ] Reviewed upcoming activities

[ ] Stopped to use the facilities (water, restroom, etc.)

[ ] Rented/borrowed equipment (binoculars, etc.)

[ ] Other:

20. When did you stop at the visitor center today?

[ ] Before beginning my exploration of the refuge

[ ] Part-way through my visit to the refuge

[ ] After hiking or exploring the refuge, on my way home

21. Did you encounter our welcome statement at the entrance? Yes No

If yes, what were your thoughts?

22. Did you hike on the trails outside of the visitor center today? Yes No

23. If yes, did the interpretive signage and educational panels improve your experience at the refuge? Yes No Not Applicable

24. If yes, what did you learn about from the interpretive signage and educational

panels? (Mark all that apply.)

[] History of area

[] Local wildlife

[] Settler or pioneer history

[ ] Local plants

[ ] Native American culture and perspectives

[ ] Native American archaeology 
25. Which of the following types of live programs, if offered, would encourage you to

return to this refuge in the future? (Mark all that apply.)

[] Programs for youth

[ ] Programs for family/multiple generations

[] Programs that teach skills to visitors

[] Programs that highlight Native American culture

[] Programs that offer environmental education

[] Other:

26. What did you think of the Native American perspective featured in the interpretive and educational panels inside the visitor center and along the trails?

27. Before you visit, did you know this site is a part of Nuwu/Nuwuvi (Southern Paiute) traditional territory?

[ ] Yes [] No

28. Does knowing this site is part of Native American traditional territory influence

your desire to support conservation activities at this site?

[] Yes [] No [] Maybe

29. Would you like to see more interpretation related to Native Americans at this site?

[] Yes [] No [] Maybe

30. Please rate how much you agree with each statement. During my visit to the

refuge, I have... [5 pt Likert scale: Completely Disagree to Completely Agree]

a. Thought about my personal values.

b. Thought about my place in the world.

c. Improved my connection with nature.

d. Improved my understanding of human-nature relationships.

e. Deepened my appreciation for public lands. 